\title{
THE THEORY OF HARD CASES AND HUMANITARIAN INTERVENTION
}

\author{
Sebastian Sykuna, Jerzy Zajadło*
}

In the modern theory and philosophy of law the concept of so called hard cases is often associated with Anglo-Saxon legal culture and especially with Ronald Dworkin's integral philosophy of law ${ }^{1}$, which is unsurprising. The problem of hard cases is directly proportional to the role played in the system of law by organs applying the law, especially the courts. It certainly does not mean that hard cases are to be found exclusively in the common law model and that they are absolutely alien to continental legal culture. In the authors' opinion, it should be assumed that this is a narrow, perhaps overly narrow, meaning of the discussed concept since it is limited to the process of law application and, as a result, also to its interpretation. In Polish literature invoking Dworkin's works the following definition may be found: "Hard case in its most general presentation occurs when a judge does not have at his disposal an explicit norm made

* University of Gdańsk.

1 M. Zirk-Sadowski discussing two most prominent Dworkin's Works, Taking Rights Seriously and Law's Empire, writes: “In Taking Rights Seriously the aim of Dworkin's discussion was to demonstrate the way of defining limits of law in so called hard cases Law's Empire was dedicated to reconstruction of mechanisms of application of such defined law"; M. Zirk-Sadowski, Wprowadzenie, in: R. Dworkin, Imperium prawa, transl. J. Winczorek, Oficyna Wolters Kluwer Polska, Warszawa 2006, p. XIV. 
by certain authority, but also cases involving decision-making problems resulting from the lack of consent among lawyers"2.

Accepting also the aforementioned, narrow meaning of the discussed concept, it may be considered correct when it is deployed to discuss issues which are at once especially complex and appalling for public opinion. The most evident example may be legal proceedings concerning cases of genocide $-\mathrm{S}$. Landsman titled his book dedicated to the Nuremberg Trials and well-known cases of Adolf Eichmann, John Demianiuk and Imre Finta in a very distinctive way: "Crimes of the Holocaust: The Law

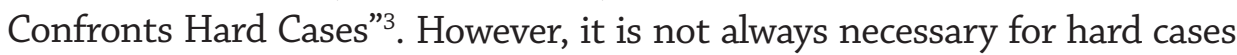
to be so spectacular. Daniel E. Lee discusses in this context the question of a state's interference with the freedom of individuals in such cases as e.g. the obligatory wearing of helmets by motorcyclists, euthanasia supported by a doctor, the use of marihuana, abortion or parents' refusal concerning medical treatment of a child ${ }^{4}$. Some authors use the notion "hard cases" in relation to complicated constitutional issues ${ }^{5}$ and complex problems arising in regimes violating human rights and subsequently resolved during transition periods with the use of so called transitional justice ${ }^{6}$. The latter examples are especially interesting since they are connected with fundamental questions concerning the limits and

2 B. Wojciechowski, Rozstrzyganie tzw. trudnych przypadków poprzez odwołanie się do odpowiedzialności moralnej, Studia Prawno-Ekonomiczne, 2004, Vol. LXX, at p. 11.; see also S. Sykuna, J. Zajadło, "Sprawy konstytucyjne" w integralnej filozofii prawa Ronalda Dworkina, Gdańskie Studia Prawnicze, 2004, Vol. XII, at p. 288 et seq., and S. Sykuna, Trudne przypadki, in: J. Zajadło (ed.), 'Leksykon współczesnej teorii i filozofii prawa', Wydawnictwo C.H. Beck, Warszawa 2007, at pp. 339-340.

3 S. Landsman, Crimes of the Holocaust: The Law Confronts Hard Cases, Pennsylvania University Press, Philadelphia 2005; there are also publications defining in general the issue of prosecuting perpetrators of massive violations of human rights as hard cases, especially in the context of so called universal jurisdiction - see e.g. International Council on Human Rights, Hard cases: bringing human rights violators to justice abroad, Versoix (Switzerland) 1999.

4 D.E. Lee, Freedom Vs. Intervention: Six Tough Cases: Six Hard Cases, Rowman\&Littlefield Publishers, Lanham 2005.

5 See e.g. L.A. Kloppenberg, Playing It Safe: How the Supreme Court Sidesteps Hard Cases and Stunts the Development of Law, New York University Press, New York 2002.

6 See e.g. D. Dyzenhaus, Hard Cases in Wicked Legal Systems: South African Law in the Perspective of Legal Philosophy, Clarendon Press 1991; more on this subject: R. Teitel, Transitional Justice, Oxford University Press, Oxford-New York 2002. 
possibilities of applying instruments of law (especially of criminal law) in the process of critically reviewing the past and taking history to court ${ }^{7}$.

A distinction between hard and soft case has recently been adopted in English language literature by B.H. Bix. In his opinion, the difference may be considered in three aspects: degree, time and certainty of consensus which may be (or may not be) achieved by well-educated and sensible lawyers in a particular case ${ }^{8}$. Hard cases understood in this manner also appear in various mutations in other authors' definitions, which differ not only as to the manner in which the essence of hard cases is to be understood but, above all, in the suggested ways in which the courts, via their interpretation and application of law, should resolve them.

For the sake of clarity, it should be noted that originally hard cases, although not literally named as such, featured in J. Austin's account of positivism and later in the sophisticated version suggested by Hart, whereas Dworkin's concept constituted an elaborate criticism of such positivism in general, and Hart's concept in particular. Without discussing similar understanding of the essence of the issue, there is no doubt that use of the notion of hard cases is commonly associated with the name of Dworkin ${ }^{9}$, although Hart, in his afterword to his foundational work "The Concept of Law" also uses similar expressions ${ }^{10}$. In 1975 Dworkin published an extensive essay entitled "Hard Cases" in the Harvard Law Review ${ }^{11}$. Characteristically, the work was an adapted version of his inaugural lecture given in 1971 upon his assumption of the chair in jurisprudence in Oxford, previously occupied by Hart. Both authors differed substantially in their approach to resolving the issue of hard cases and as to the outcome of the solution.

7 More on this subject in Polish literature: see J. Zajadło, Odpowiedzialność za Mur. Procesy strzelców przy Murze Berlińskim, Wydawnictwo Arche, Gdańsk 2003.

8 B.H. Bix, A Dictionary of Legal Theory, Oxford University Press, Oxford 2004, p. 81 et seq.

9 As e.g. R. Wacks, Philosophy of Law. A Very Short Introduction, Oxford University Press, Oxford 2006, p. 42 et seq.

10 See Polish edition of H.L.A. Hart, Pojęcie prawa, transl. J. Woleński, Wydawnictwo Naukowe PWN, Warszawa 1998, p. 364 et seq.

11 R. Dworkin, Hard Cases, Harvard Law Review 1975, Vol. 88, No. 6, at pp. 1057-1109 . 
According to Hart, who believed that the system of law consists exclusively of rules, resolving hard cases required going beyond the system thanks to, so-called, open texture notions. This gave rise to certain difficulties from a positivist perspective, since it acknowledged the potentially law-making character of a court's decision. Abandoning the model of simple subsumption and severing the direct relationship between the rule and the resolution of a particular case means that:

"the confidential way and going beyond the system of law is all that a judge has at his disposal. (...) Hart tries to circumvent difficulties connected with the position acknowledging court decision made in hard case as a law-making decision. From the point of view of positivism, it is an unacceptable solution. In that case Hart suggests that such decision should be recognized as being within the frame of standard of correct (i.e. in conformity with law) court decision. The standard is outlined by the scope of meaning of the rule containing open texture notions. Going beyond this scope means, according to Hart, going beyond the standard of correctness" 12 .

The most elaborate definition of hard cases was suggested by Ronald Dworkin, who adopts a completely different assumption ${ }^{13}$. In his opinion, rules co-exist alongside principles and policies within the legal system. Unlikely Hart's approach a judge who, when resolving a case, does not have at his disposal an explicit regulation in the sense of a rule, is not required to extend beyond the system of law. On the contrary, he is obliged to search for a solution within the system, on the grounds of principles and/or policies. In accordance with the assumptions of positivism, a judge adopting a ruling in a hard case is obliged to apply legal rules. Accordingly, he is within the legal framework and not permitted to go beyond that framework. Consequently, he is searching for an optimal solution not in general, but optimal in particular circumstances. According to Dworkin, who based his reasoning on the grounds of the integral philosophy of law, this is inadequate, or even incorrect. A Legal rule may transpire to be

12 M. Król, Koncepcje trudnych przypadków a prawomocność, [in:] 'Teoria prawa. Filozofia prawa. Współczesne prawo i prawoznawstwo', Wydawnictwo UMK, Torun 1998, at p. 99.

13 More on his concept - R. Dworkin, Biorac prawa poważnie, transl. T. Kowalski, Wydawnictwo Naukowe PWN, Warszawa 1998, esp. chapter IV, at pp. 155-242. 
insufficient for making a correct decision - appropriate, using Gustav Radbruch's rhetoric, from the perspective of justice, appropriateness or legal safety. While Hart in such situations was willing or accept that a judge possesses the authority to make a "free" decision, integral philosophy suggests staying within the system of law and demands reference to legal rules. Dworkin believes that a court ruling in hard cases should not permit the creation of new legal rules ad infinitum and that the court should search the legal system for "latent" standards in the form of principles and policies.

A certain paradox may be noticed here: a positivist Hart searches for the solution to hard cases within extralegal norms, while the non-positivist Dworkin pursues this search within rules and guidelines which are intrinsic to the legal system itself.

Assuming that the phenomenon of law covers five "dimensions" i.e. creating, applying, interpretation, binding and respecting, the issue of hard cases, on the grounds of philosophy and theory of law is, from a traditional perspective, present exclusively in the process of applying the law and as regards its interpretation.

In Polish the legal concept of hard cases, elaborated in the 1980s by J. Wróblewski, deserves particular attention. It is important to note that this author also restricts his analysis of hard and soft cases to court-type law application. Noticing the fluidity of the distinction between hard and soft cases accepted in legal discourse, Wróblewski suggested concentrating on four points of view, which he called: institutional, substantive, institutional-factual and theoretical ${ }^{14}$. The first consisted in taking into consideration regulations of procedural law "in the procedural model of court law application". Therefore, it could be assumed that taking the institutional division of jurisdiction into account, only cases examined by the Supreme Court, as the most important organ of judicial power adjudicating legal disputes, could be recognized as hard cases ${ }^{15}$. Wróblewski connected the above-mentioned position of the Supreme Court both with its institutional importance, in many cases as a kind of final instance, and its competences. As an example of the latter, Wróblewski acknowledged,

14 K. Opałek, J. Wróblewski, Prawo. Metodologia, filozofia, teoria prawa, Warszawa 1991, at pp. 273-284.

15 Ibidem, at p. 274. 
for instance, the competence to issue resolutions concerning legal questions addressed to the High Court, thanks to which doubts emerging in the process of examining cases in lower courts were removed ${ }^{16}$.

Institutional distinction did not necessarily coincide with substantive criterion. Wróblewski clearly emphasized that, taking the substantive content of a case into consideration, the High Court also deals with soft cases. This raises the question of how to identify a hard case, distinguished on the basis of factual criterion. In Wróblewski's opinion, it would be necessary to analyze the court records concerning the particular case in question. From a substantive perspective, only cases in which "divergence in the positions of participants in the process or in opinions of court instances expressed in divergent or differently justified decisions is stated"17 may be recognized as hard cases.

Combining the two aforementioned criteria, J. Wróblewski also distinguished the third, institutional-substantive point of view. It was the consequence of the above-mentioned right claim that not all cases reaching the High Court must be recognized as hard cases from a substantive perspective. The third point of view allows a certain case to be acknowledged as a hard case only when, on the one hand, it is the subject of interest for the High Court and, on the other hand, it is complex because of divergent decisions at various court instances ${ }^{18}$.

The final criterion to distinguish hard case is from a theoretical point of view. As Wróblewski wrote in his work, it is based on "the analysis of part-decisions and final court decision concerning application of law in which crucial issues affecting right justification reasoning are stated"19. In the court model of application of law a final decision is justified by several part-decisions. From a theoretical perspective, a case should be recognized as a hard case when, besides issues which are factual in character it gives rise to a dispute concerning the relationship between those considered to be proven facts related to the examined case and a particular legal rule ${ }^{20}$.

16 J. Wróblewski, Stosowanie prawa przez Sąd Najwyższy, Nowe Prawo 1985, Vol. 5, at p. 25.

17 K. Opałek, J. Wróblewski, op. cit., at pp. 274-275.

18 Ibidem, at p. 275.

19 Ibidem, at p. 275.

20 M. Król, op. cit., at p. 107. 
In the theory of legal arguments, it is possible to discover a narrow meaning of hard cases. In Polish literature on the subject, J. Stelmach states that hard cases are the essential element of practical argumentative discourse in general, and legal discourse as its variation in particular. Practical discourse is pointless when it concerns simple, uncontroversial, explicit cases, which do not give rise to doubts:

"We start a discourse only when it concerns a so called hard case, i.e. a case which cannot be adjudicated by applying standard methods of interpretation - only theoretical discourse. It was solely because of examining such cases that the whole modern theory and philosophy of legal argument developed"21.

However, just as in Hart's and Dworkin's works, the theory of legal argument uses the category of hard cases exclusively as regards law application and interpretation. a legal discourse correctly conducted should be tightly connected with applicable law:

"If the legal dispute were not direct related to the application of law (yet such possibility exists), it would simply be an ethical dispute. Legal discourse, in order to be legitimate and effective, must therefore have a dogmatic character. (...) The starting point for legal argument is to determine the law applicable in a controversial case. Any preliminary findings, still mostly made within the framework of theoretical discourse, enabling us to establish the factual and legal condition of the case in question, are then findings de lege lata. Practical legal discourse transfers us to the sphere of findings de lege ferenda, or postulated law. (...) In simple cases, findings based on theoretical discourse are sufficient and their settlements are essentially algorithmic (repetitive) in character. Entering into practical discourse, we begin to "seek the law", somehow automatically, moving onto the plane of findings de lege ferenda which, of course, must always be in "direct connection" (i.e. must be consistent) with applicable law, even when they lead to a precedential decision"22.

21 J. Stelmach, Kodeks argumentacyjny dla prawników, Kantor Wydawniczy Zakamycze, Kraków 2003, at p. 38; and more also see J. Stelmach, Współczesna filozofia interpretacji prawniczej, Wydawnictwo UJ, Kraków 1999 and J. Stelmach, B. Brożek, Metody prawnicze, Wolters Kluwer Polska, Kraków 2006.

22 Ibidem, at pp. 59-61. 
On the grounds of the theory of legal interpretation, another very important difference in Dworkin's and Hart's concepts is raised. According to Dworkin, there is only one correct answer to hard cases ${ }^{23}$, which exemplary judge Hercules should give referring to the principles and guidelines that are part of the law. If this were indeed the case: firstly, practical discourse would be unnecessary and could be limited to theoretical discourse; and secondly, in fact such a case should be considered as a simple case, as opposed to a hard case. Thus, it is exactly the opposite - the essence of a hard case consists in the fact that in the process of argumentative discourse it is possible to arrive at several conclusions, each of which may be justified on the grounds of accepted criteria of rationality and correctness. Then, and only then, additional criteria enabling the choice of one such conclusion, may complement the discourse ${ }^{24}$.

Both Dworkin ${ }^{25}$ and theoreticians of legal argument ${ }^{26}$ quote a case resolved by the Court of Appeal in New York in the late XIXth century - Riggs v. Palmer (verdict of 8.12.1889) as a classic example of a hard case. The case concerned whether or not a murderer could inherit from his victim's estate. Dworkin describes the case in the following way:

"In 1889, a New York court had to decide in the famous case Riggs v. Palmer whether the successor referred to in the last will of his grandfather could inherit under it, despite the fact that for this reason he killed his grandfather. The court proceeded to reasoning with the following assumption: 'It is true that the laws governing the production, certification and execution of wills and the transfer of ownership, with their literal interpretation, and if their power and effects cannot be controlled or altered in any way and under any circumstances, award the property to a murderer'. The court, however, further notes that 'all rights and contracts may be reviewed as to their

23 R. Dworkin, Is There Really No Wright Answer in Hard Cases?, [in:] R. Dworkin, 'A Matter of Principle', $9^{\text {th }}$ edition, Harvard University Press, Cambridge (Mass.), London 2000, at pp. 119-145.

24 J. Stelmach, op. cit., at p. 15 et seq. and p. 20 et seq.

25 R. Dworkin, op. cit., passim.

26 J. Stelmach, B. Brożek, op. cit., at p. 87 et seq.; in Polish literature this example, after Dworkin, is referred to also by e.g. L. Morawski in Główne problemy wspótczesnej filozofii prawa. Prawo $w$ toku przemian, $3^{\text {rd }}$ edition, Wydawnictwo Prawnicze LexisNexis, Warszawa 2003, at p. 307. 
operation and effects due to the basic principles of common law. Nobody can benefit from the fraud committed or harm made by himself nor can he base his claims on wickedness or acquire property through crime'. The murderer did not receive his inheritance" ${ }^{\prime 2}$.

According to Dworkin, this is a classic example of hard case, where the rules of law do not allow a satisfactory verdict to be achieved. However, it is not necessary to seek for solutions outside the legal system. On the contrary, the rule ex iniuria ius non oritur permits the court to deny Elmer Palmer the right to inherit from his grandfather, Francis Palmer, in spite of the latter's will. In other words, "the legal rule that 'nobody can benefit from the evil he had committed' produces an exception to the legal rule according to which Elmer was to inherit from his grandfather" 28 . However, it must be added that the court's judgment was not unanimous. Judge J. Gray delivered a dissenting opinion which argued that the case should be decided on the basis of the applicable rules of law, which would not have denied Elmer Palmer his inheritance. He argued that, as a convicted murderer, he would already suffer the legal consequences of his criminal act and there was no legal basis to punish him also within the framework of the law of succession. Primary concern should be given to the expressed will of the deceased. It is not possible to anticipate negative reviews, since it is not possible to know whether or not Francis Palmer would have chosen to disinherit his grandson, knowing that he would be murdered by him. It is not beyond the realms of possibility that the grandfather's deep feelings towards his grandson and family ties would prevail.

The case would not be treated as hard on the grounds of modern civil law. There is, for example, the following regulation in Article 928 of the Polish Civil Code:

$\S 1$. A successor may be found by the court to be unworthy, if he:

1) intentionally committed a crime against the devisor;

2) with the use of deceit or threat urged the devisor to draw up or cancel a will or in the same way prevented him from performing any of these operations;

27 R. Dworkin, op. cit., at p. 57 et seq.

28 J. Stelmach, B. Brożek, op. cit., at p. 88. 
3) intentionally concealed or destroyed the will of the devisor, forged or transformed his will, or consciously benefited from the will forged or transformed by a third person.

$\S 2$. An unworthy successor is excluded from inheritance as if unable to attend the opening of the will.

J. Stelmach i B. Brożek make a detailed logic analysis of the Riggs v. Palmer case and highlight a particular practical danger resulting from the judgment of the New York court:

"The rules may 'produce' exceptions to the rules in specific cases, and the number of such exceptions is theoretically unpredictable. Thus, a full formalization of any rule of law can never be given as there is always a possibility that in an unforeseen situation a kind of rule would 'produce' an exception" 29 .

It seems however, that this is the very essence of hard cases.

In English literature, N. McCormick has expressed his criticism of R. Dworkin's concept ${ }^{30}$. First of all, it is noteworthy that in his opinion hard cases concern all disputes during court proceedings. Furthermore, according to McCormick, they also cover both factual and legal issues. The main objection addressed by McCormick towards Dworkin concerned the fact that the latter, on the grounds of positivism, limited hard cases exclusively to lawmaking situations. McCormick, referring to the idea of W.D. Ross's "duties prima facie", constructs his definition of hard cases on "rights prima facie" and understands them as a party's potential rights in court proceedings. Their potentiality is seen in the fact that it is only after the conflict between principles and values has been settled that specified subjects are granted these rights. In Polish literature, N. McCormick's concepts were introduced by M. Król, who stresses that it is the idea of rights and duties prima facie that is the basis for McCormick's definition of the concept of hard cases as situations in which "each party has grounds on which they demand their rights of at least right prima facie character" ${ }^{31}$.

29 Also there, at p. 89.

30 Quoted after M. Król, op. cit., at p. 103.

31 Ibidem, at p. 104. 
Distinguishing between simple and hard cases, McCormick sees the main difference as lying in the justification of court decisions. While in simple cases the reasoning of the decision of the law-applying body is based on straightforward deduction of clear legal rules, in hard cases, prior to the deduction, it is necessary to interpret those legal rules or sometimes even consider other issues, which in consequence entails the need for justification at a second level ${ }^{32}$.

Describing the issue of hard cases, M. Król also refers to A. Peczenik's suggestions that the concept of hard cases is a developed theory of jumps ${ }^{33}$. Originating from the idea of law transformation, A. Peczenik considered that the role of the judge is to transform established sources of law into interpreted "applicable law". This transformation is based on the above-mentioned jumps, as opposed to deductional steps of reasoning ${ }^{34}$. The constraints of this article do not permit us to analyze the whole concept of jumps by A. Peczenik ${ }^{35}$. It is noteworthy however, that such jumps were represented by the hard cases which Peczenik considered to account for the reasons of jumps leading to the transformation of law. As may be surmised, Peczenik's references to judicial reasoning analyzed the essence of hard cases exclusively on the grounds of law application where, in the process of explaining the reasoning behind their decisions, judges apply this technique of jumps. In fact, it is possible to discuss hard cases in which it is insufficient to rely only on sources of law while explaining the reasoning behind a decision. As M. Król wrote, hard cases for Peczenik "are resolved on the basis of compromise between axiological legal premises and the judges' own axiological options" 36 . The above comments aimed to: firstly, confirm the existence of the phenomenon of hard cases; secondly, to determine its conception on the grounds

32 N. McCormick, Legal Reasoning and Legal Theory, Oxford 1978, chapter VIII, at p. 198; quoted after M. Król, op. cit., at p. 103.

33 M. Król, op. cit., at p. 105. As for the details of A. Peczenik's theory of jumps see also the article by the same author published in 1996 under the distinctive title Jumps and Logic in Law. What Can One Expect from Logical Models of Legal Argumentation?, Artificial Intelligence and Law 1996, Vol. 4, No. 3-4, at pp. 297-329.

34 Ibidem, at p. 105.

35 See also A. Peczenik, On Law and Reason, Dordrecht/Boston/London: Kluwer Academic Publishers 1989, at pp. 114-118 and 130-131.

36 Ibidem, at p. 106. 
of modern theory and legal philosophy, especially the philosophy of legal reasoning. So we are dealing with a well-established paradigm, from which this article is exception. For its needs we adopt a much broader and a slightly different conception of the essence of both hard cases and the scope of the practical application of legal discourse. Our goal is to present several examples which are not necessarily within the above definition of hard cases which does not mean that they do not possess such character on the basis of conventional assumptions given below.

Firstly, we believe that hard cases occur not only in the process of applying and interpreting the law, but may also be discovered in other "dimensions" of the phenomenon of law, such as the creation, application and observance thereof. In this sense, a factor in deciding whether the case is hard or easy is the possibility of multiple solutions which may be justified in the course of practical legal dispute on the basis of accepted criteria of rationality and fairness. Hard cases in this sense are not merely the domain of the judge seeking to resolve a specific case when a clear rule of law is unavailable. Similar problems may also be encountered, on the one hand, by the legislator when deciding whether or not to regulate particular social relations and, on the other hand, by citizens appealing to the institution of civil disobedience or abstention therefrom. This does not alter the fact that hard cases indeed are mainly to be found in judicial practice in the process of applying or interpreting the law. It also concerns the sphere of law application, for instance, when a court faces an extremely rare and at the same time highly dramatic choice arising from confrontation between rules dura lex sed lex and lex iniustissima non est lex. The history of recent decades clearly shows that the choice is not merely a purely hypothetical fantasy of legal philosophers. We are not so much interested in specific decisions taken in hard cases but rather in more general problems accompanying the arrival at such a decision.

Secondly, we renounce the absolute acceptance of the above-discussed thesis concerning the need of reasoning in direct connection with applicable law. We believe that this limits the concept of hard case, since it refers only to the existence thereof within the sphere of applying and interpreting law. While we acknowledge that a direct link with applicable law in the process of legal discourse will often be present, the extension of hard cases to, for example, the lawmaking process may mean that the link becomes unnecessary. Sometimes a legislator faces 
a decision which does not have a direct connection with applicable law as it enters the area of terra incognita. Concurrently, we believe that the absence of a direct connection with applicable law does not automatically mean that practical discourse is incapable of being referred to as legal discourse and that it is automatically shifted to the plane of ethical discourse. The essence of legal discourse, for the purpose of this study, is determined not by the need for a direct link with applicable law but rather by the legally relevant subject matter of the discourse within the framework of hard cases, understood in this manner.

Thirdly, we recognize that hard cases occur mainly where there exists a clash of law with other normative systems. Traditionally, it is stressed that this mainly concerns the relationship between law and morality - according to some authors, this is the area where the concept of hard cases should be applied in a much broader sense than that in which it is currently accepted in modern legal theory and philosophy ${ }^{37}$. While, for the purposes of this article, we confirm that the problem of conflict between legal norms and moral norms is of fundamental importance ${ }^{38}$, we also submit that it is worth highlighting other areas in which such conflicts may have significant effects - in particular: morals, religion, politics, economics, ecology, legal ethics and scientific and technological progress. In each of them, it is possible to discover examples of broadly understood hard cases because we are faced with the need to choose between various, rationally justified and correct solutions. Thus, there always exists a choice between competing values - in this sense, argumentative legal discourse is also axiological discourse. Furthermore, moral dilemmas may arise not only in conflicts between law and ethics but also in other areas such as

37 So e.g. D. Bunikowski, Ingerencja prawa we sferę moralności w trudnych przypadkach (http://www.racjonalista.pl/kk.php/s,4621). It is necessary to stress that the authors of this article are not isolated in this different and very broad understanding of so called hard cases - see e.g. recently C. Abbt, O. Diggelmann (eds.), Zweifelfälle, Nomos Verlag, Baden-Baden 2007, pointing to the clash of law, philosophy and politics.

38 For example, D. Lyons generally combines the problem of hard cases with moral decisions - see Etyka i rzqdy prawa, transl. P. Maciejko, Dom Wydawniczy ABC, Warszawa 2000, at p. 84 et seq.; in Polish literature hard cases have recently been combined with judicial ethics issues - see T. Romer, M. Najda, Etyka dla sędziów. Rozważania, Wolters Kluwer Polska, Warszawa 2007. More on the clash between law and morality see M.H. Kramer, Where Law and Morality Meet, Oxford University Press, Oxford 2004. 
the media, medicine, morality, politics, etc ${ }^{39}$. Such hard cases which are within the paradigm determined by Hart - Dworkin dispute should not be ignored. In this case however, it is recognized that the problem does not concern the conflict between law and other normative systems, but paradoxically - the conflict of law with itself and therefore the conflict between law and law. Last but not least, it is necessary to deal with hard cases whose solution would simply require reference to rules of prudence and so called common sense. As a typical example, one may refer to the fierce dispute in the modern science of law concerning the issue of legality and legitimacy of humanitarian intervention. Recently it has been indicated that the seemingly intractable conflict between ethics, politics and law requires perhaps reference to common sense morality ${ }^{40}$. This is all the more important as the reference to the category of common sense is especially popular in the Anglo-Saxon culture of law from whence the idea of hard cases originates. An example of humanitarian intervention within the categories of hard cases implies an alternative understanding of that concept. Specifically, it may be said that they occur in situations where there is a discrepancy between legality and legitimacy - moral, political, economic, environmental, religious, etc. The essence and methodology of the dispute ongoing even during the Weimar Republic in German philosophy of law under the banner of Legalität und Legitimität, remains present ${ }^{41}$, although it is clear that the notion of hard cases was not utilized then. Moreover, although the dispute concerned the legality and legitimacy of the political-legal order as a whole, it may also be transferred to other areas of individual norms within the system.

Assigning the status of hard cases to certain conflicts within legal norms or between law and other normative systems and common sense rules is, to some extent, symbolic in nature - sometimes it is difficult to precisely isolate problems occurring at a point at which converge, for example, morality and social morals, politics and economics, law and legal

39 See O. Ezra, Moral Dilemmas in Real Life. Current Issues in Applied Ethics, Law and Philosophy Library, Vol. 74, Springer Verlag 2006.

40 So e.g. E.A. Heinze, Commonsense Morality and the Consequentialist Ethics of Humanitarian Intervention, Journal of Military Ethics, 2005, Vol. 4, No. 3, at pp. 168-182 .

41 More on the subject: D. Dyzenhaus, Legality and Legitimacy, Oxford University Press, Oxford 1999. 
ethics, science and religion, etc. This is equally applicable to common sense rules which are outside ethical or political spheres.

In our opinion, it is possible to distinguish several cases in which conflicts between law and other normative systems or common sense rules exist, thereby permitting discussion of hard cases. First of all, we accept that the conflict within the law itself is possible which implies the need to identify the situation of law versus law. Next we can talk about a conflict between law and morality, social morals, religion, science, medicine, history, politics, media, economics, ecology, legal ethics, common sense. Some of these distinctions as, for instance, law versus morality seem to be obvious and are described in detail in literature. In our opinion however, they also should be briefly reminded of and supplemented with certain exemplifications. It is in no way our aim to provide a thorough and exhaustive presentation of the clash between law and other chosen normative systems and the consequences resulting therefrom. This assumption is only partly due to the limitations imposed by the publishing frames of this article. Fundamentally, we believe that reference to brief but explicit examples will suffice to present our broad understanding of hard cases.

Firstly, considering conflicts within the law itself, we do not talk about such situations commonly known to lawyers where conflict rules are applied when dealing with apparent and real contradictions in law. As discussed in the methodological assumptions above, our reference to hard cases incorporates slightly different types of conflict. It could be seen in already discussed dispute between Dworkin and Hart, and especially in the manner dilemmas in Riggs $v$ Palmer were settled. Above all, Gustav Radbruch's concept of the idea of law represented our starting point of reference. According to this author, as it is commonly known, it consists of three elements: security, usefulness and justice. The problem, however, is that there may be - to use Radbruch's rhetoric - various kinds of antimonies between individual components of the idea of law. It is not always the clash between law and other normative systems (e.g. morality), but sometimes a conflict within law itself. The most dramatic situations occur on the borderline between security and justice. In easy cases, a lawyer will seek the solution in favour of security, sometimes at the cost of justice, guided by the trite slogan dura lex sed lex. In hard cases, the issue may be more complicated. Sometimes justice will win; 
sometimes however in an equally rational way we may defend the value of legal security even if the accepted solution will conflict with our sense of justice.

Morality is a classic example of another normative system which clashes with law. In our opinion, a conflict of this type is the core of hard cases. The most numerous examples of such situations and the most complicated problems may be found in this area. Moral-legal dilemmas have the longest tradition and at the same time remain relevant today. It suffices to say that the classic dispute between the doctrines of law and legal positivism has now adopted the form of controversy between positivism and non-positivism, whose essence lies in defining the relationships between law and morality.

In more recent literature on this subject, four potential theoretical approaches are identified:

1) ethical and legal nihilism, recognizing the absence of any relationship between law and morality (e.g. Scandinavian legal realism),

2) ethical and legal reductionism, recognizing that although such relationships exist they are not necessary in character and are not desirable (e.g. H. Kelsen),

3) ethical and legal prescriptivisim (normativism), recognizing that such relationships exist and that, even if they are not necessary in character, they are desirable (e.g. H. L. A. Hart),

4) ethical and legal essentialism, recognizing that such relationships not only exist but they are necessary in character (e.g. R. Dworkin).

In our opinion, it is possible to identify three other classifications of ethical-legal disputes. The first group may include such dilemmas which are relatively new and therefore not yet resolved - they are connected on the one hand, with scientific and technical development (e.g. the issue of genetic engineering), and on the other, with changes in morality (e.g. the issue of legalization of partner relationships of persons of the same sex). The second group includes, in turn, well-known and traditional disputes in which actually everything that has to be said has already been said and which are, to some extent, irresolvable given the vastly different starting points of adversaries - such as issues of abortion, euthanasia or capital punishment. Finally, the third group of ethical-legal disputes concerns such issues which were resolved long ago, both in the moral and juridical sense, and to which therefore we do not wish to return 
(e.g. the problem of the ban on slavery and servitude, or the ban on torture and cruel, inhuman and humiliating treatment).

Considering the nature of conflict between law and morality certain regularities may be illustrated. Firstly, it is extremely difficult to distinguish hard cases occurring on the borderline between law and morality from other areas of potential conflict, e.g. law and history, law and medicine, law and science, law and morals, law and politics, law and religion, etc. Secondly, continuous and incessant progress in civilization means that ethical-legal disputes regarded as settled long ago, unexpectedly and, at times, paradoxically, transpire to remain relevant today. Thirdly, even so called irresolvable disputes in which theoretically everything has already been said that was to say, remain the subject of ethical-legal discourse.

Writing about the clash between law and other normative systems we intended to indicate the conflict which may occur on the borderline of law and morality. We are aware however, that it would be equally correct to refer to this as the conflict between "Law and Culture". Deliberately and consciously we have adopted an alternative terminological convention - at the same time we would like to stress that we use the narrow concept of morals and distinguish them, on the one hand, from custom and customary law and from morality, and on the other, from other elements of culture in its broad sense. We consider mainly some groups of norms which, on the one hand, outline the time-honoured rules of specific codes of conduct typical for certain social groups and, on the other, enter a very delicate sphere of human sexuality and sex life. In this sense, morality is an element of culture or even perhaps culture per se. We realize that the borderline between moral and customary norms is vague and fluid. Using two examples we will try to prove that in this sphere hard cases may occur.

The first example indicates firstly the clash of certain specific cultural norms characteristic for different kinds of minorities (religious, ethnic, national, racial, etc.) with the law binding in a given society as a whole. One of the basic assumptions concerning the modern democratic state of law is the principle of equal rights of all citizens. Even if we find this to be dogma, the question arises as to whether in practice there would not be situations entailing its verification. Should the minority governed by time-honoured rules resign from them and totally submit to the standards accepted by the majority, or vice versa - should the law take into account, 
sometimes at the expense of the principle of equal rights of all citizens, these specific cultural norms? The above questions arise spontaneously when we consider the phenomenon characteristic for common law which takes the form of the institution called cultural defense. It is often assumed that it may be used in situations when the body applying law takes (or does not take) into account specific cultural norms characteristic for a certain social group, norms which differ substantially from accepted standards of society as a whole ${ }^{42}$.

The second example concerns the right to interfere in the privacy of individuals in a very delicate sphere of their sex life. In this sense, the difference between morals and morality is blurred although we are aware of its existence and importance. Is sexuality really exclusively a private matter of individuals or perhaps, in some situations, it becomes an element of social life? If the answer to the first question is negative and to the second - positive, then where is the borderline whose crossing justifies legislative fiat interference? Should we also in this case take into account (and to what extent?) cultural difference of certain minorities, thinking for example about incest, or perhaps the standard for society as a whole, or even for humankind should be determined? How should law be created, applied and interpreted to avoid the trap of a false dichotomy - either moral tolerance within a pluralistic and multicultural society or moral imperialism or even paternalism of the majority?

Another conflict involving hard case may arise on the borderline between law and religion. However, understanding the essence of these hard cases may be especially difficult due to modern, but from historical point of view as a matter of fact only apparent, differences between these two spheres. Quoting at this point the title of a known work of Romanian historian and philosopher M. Eliade, it may be said that religion still remains in the sphere of sacrum, while law is in the sphere of profanum.

Four very important things however, should be remembered. Firstly, originally law was closely linked with religion, and indeed religion was its source, and our distant ancestors did not distinguish or oppose the sphere of sacrum and profanum. Secondly, the process of secularization

42 J. van Broeck, Cultural Defence and Culturally Motivated Crimes (Cultural Offences), European Journal of Crime, Criminal Law and Criminal Justice, 2001, Vol. 9, No. 1, at p. 5 . 
of the state began only a few centuries ago in Europe and against the long history of civilization constitutes merely a territorially limited episode of modernity and postmodernity. Thirdly, many of the modern legal institutions kept their peculiar religious origin while even a secular state tries to regulate at least some spheres of sacrum applying legal norms as profanum. And finally, we tend to judge modern relationship between law and religion exclusively from the perspective of the Western world in its broad meaning, often forgetting that the same problem is perceived differently in different cultures. Characteristic exemplification of the conflict arising at the meeting of law and religion may be the famous Socrates trial which was held in the period when sacrum and profanum were not distinguished. On the other hand, however, specific hard cases may occur when there is a conflict between legally guaranteed freedom of art and legally protected religious feelings.

Contrary to all appearances, finding contemporary examples of existence of another types of conflict, i.e. between law and science proved difficult. It is necessary to point to, for example, such cases in which solutions adopted by the legislator (ergo - also specific court decisions) go "against the current" of scientific progress, especially when they contradict laws of nature or proven scientific theories. Besides, even if such examples exist they: firstly, concern the past rather than the present; secondly, are never restricted only to science but concern also, and perhaps above all, other areas described in this article, for example, ecology, economics, medicine, morality or religion. The case, once well-known and on which the famous film of 1960, "Inherit the Wind" was based, concerning the ban on teaching Darwin's theory of evolution in schools in some states in the USA could be identified as a classic exemplification of such situations. In fact, this amounted to most very unfortunate interference by the legislator and judicial authorities in the conflict between science and religion, rather than a conflict of law with science per se. Moreover, it transpired that the problem is not as outdated as it might seem. In 2005 one of the courts in Pennsylvania was again required to rule on which theory - creationism or evolution - should be taught in schools. And interestingly, another film ("Dover") was based on this case.

Not forgetting these objections, and wishing to illustrate the conflict which occurs at the place where law and science meet, some problems are noteworthy. They may be expressed in the following questions: does 
progress in law keep pace with progress in science and technology?; is law an effective instrument of balancing the benefits and risks involved in developing science and technology?; how should access to the latest achievements of the human mind be combined with the idea of global distributive justice, on the one hand, and protection of copyrights on the other?

The purpose of this study is to present practical aspects of the philosophy of law. Therefore, discussion concerning law and medicine is, to some extent, of specific character: on the one hand, a very large number of hard cases occur in this sphere, and on the other hand, they are extremely complicated. Nowadays, it is even possible to isolate within legal science a particular trend which is sometimes referred to as bio-jurisprudence. Indeed, hardly any plane can be more spectacular for hard cases than that concerning the fundamental problems of human life - beginning from the moment of conception and ending with death. In this sphere we deal with traditional, eternal and, in a sense, irresolvable dispute (e.g. abortion or euthanasia). However, new dilemmas and challenges arise alongside progress in science and technology (such as genetic engineering) - here in turn we are faced with the need to formulate new, as yet unknown, ethical-legal standards.

It is hard not to notice that hard cases arising at the meeting of law and medicine are often at the same time dilemmas on the borderline between law and morality. But it is not only in this sense that the clash between law and medicine is a multifaceted issue, since it also relates to other spheres where hard cases may be found, such as law and science, law and economics, law and religion, etc. It must be admitted that there is an excess or "oversupply" of examples of such conflicts. Aside from examples referring to traditional and familiar disputes (e.g. abortion or euthanasia), reference should be made to new and particularly relevant phenomena, such as issues accompanying the institution of surrogate motherhood or access to medicines for the world's poor people in connection with protection of intellectual property.

Law also comes into conflict with history. The same conclusion applies to the whole process of reviewing history following the fall of the communist system in Europe. We mean here the application of legal instruments for reviewing the past. Although in such cases it is also possible to categorize this as a conflict between law and politics, 
nevertheless in our opinion the elements of history, strictly speaking "policy towards the past" (German Vergangenheitspolitik) and so called "transitional justice" (or "retrospective justice") are most prominent.

The collapse of communism revealed that the discussed problem is extremely complicated. A rational policy towards the past should aim to achieve five basic objectives:

1) establishing the truth,

2) inflicting punishment,

3) moral condemnation,

4) restitution and redress for injustice, and

5) cultivating memory.

It should not be forgotten however, that the problem of so called historic injustice is not restricted only to the faults of communism within one country and has a much broader dimension. A policy towards the past comprises more than merely redress for intergenerational harm but also international (vide - the effects of war), and sometimes even inter-civilization (vide - the legacy of colonialism).

Law is not the sole, and not always the best, instrument with which to carry out such an understood policy towards the past, as in general "taking history to court" requires extraordinary caution and prudence. The Polish vetting and decommunization experience proves how complicated and sensitive this matter is. In this sense, the clash between law and history often leads to hard cases in the broadest meaning of the term. Law, as an instrument of reviewing the past, is very helpful and, in terms of achieving objectives No. 2 and 4, it is in fact necessary.

Objective No. 2 refers to criminal law and concerns individual responsibility for crimes committed in the past in a lawless state - therefore it is retrospective justice imposed by a court in a criminal trial. It should be remembered however, that ultimately it is not history, but rather the individual embroiled in it, which is on trial. The trials of so called shooters at the Berlin Wall (Mauerschützenprozesse) may be offered as examples of such cases.

In practice, achievement of objective No. 4 is even more complicated. We deal here with another type of retrospective justice - it is corrective justice aimed primarily at restitution in the field of property as a means of compensation for harm inflicted on people during the previous period. It is accomplished by means of, inter alia, legal instruments, although these are 
not instruments characteristic of the criminal law but rather of administrative and civil law. Consequently, the law conflicts here not only with history, and consequently with politics, but very often with economics, which is best demonstrated by the re-privatization process in Poland after 1989. Another, suggested by us, type of hard cases concerns the clash between law and politics. It is submitted that such situation are the greatest threat to law, and especially to the conception of law as harmony between security, relevance and justice. This is chiefly caused by the fact that politicians, on the one hand, practice politics and, on the other hand, in a representative democracy ultimately determine the shape and content of legal norms. Inevitably, as a result, this may create two very serious threats - firstly, sometimes the short-term and opportunistic, and sometimes even long-term primacy of politics over law; and secondly, the instrumentalization of law for the needs of politics. This concerns both the sphere of international and domestic relations. In the first case it may be still not settled issue of humanitarian intervention, and in the other, native to us, case of late submission by the mayor of Warsaw of financial disclosure of his spouse.

Sometimes the dilemmas on the borderline of law and politics are accompanied by complicated moral problems. The outstanding German expert on international law, M. Bothe, in the context of NATO military intervention in Kosovo stated that "if the clash between law and ethics occurs, something must be wrong either with the law or ethics". Paraphrasing this statement it may be noted that there is usually nothing wrong with law, moral intuition is also, as a rule, right and this is so called Realpolitik which often disappoints us.

This results from a certain historic paradox. In practically all languages of the world, including Polish, such words as "law" and "ethics" have definitely positive semantic connotations. By contrast, the word "politics" has recently undergone certain strange, paradoxical and ambivalent changes. For the average modern man, the term has negative connotations, although its ancient prototype had strong positive overtones. Perhaps we should return to an Aristotelian understanding of politics as actions for the common good (ergo - good of humanity, mankind) and in this way remove the above-mentioned threats to the idea of law posed by an improper understanding of Realpolitik?

The vast majority of conflicts between law and other normative systems which, in our opinion, may be referred to as hard cases are, in 
a sense, timeless and are not products of the present. On the contrary, moral, political or religious dilemmas connected with law have an extremely long history. This issue is slightly different with reference to such areas as economics, ecology or science, since even if hard cases may have occurred earlier, their existence and essence was not always realized. Undoubtedly, in comparison with the past, modern civilization provides many more examples of conflicts on the borderline between law and economics, law and ecology or law and science.

In the case of another type of conflict, which occurs at the point where law and media converge, we are faced with a completely different situation because they never played such an important role as they currently do and, besides, they are in a sense and to some extent exclusively the product of modernity and postmodernity. The number and complexity of questions and doubts arising in modern democratic societies on the borderline between law and the media is so huge that they are very difficult to be discussed in accordance with the convention adopted in this study. Suffice to say, the spectrum of problems stretches from constitutional law, administrative, civil, commercial, criminal, international, procedural law as far as financial law and it virtually spans the entire system of a democratic state of law.

Without going into details concerning theoretical considerations of the aforementioned conflict, the infamous trial of O.J. Simpson is worth mentioning here. In our opinion, it clearly demonstrates that a confrontation between the legally guaranteed freedom of the media and other legally protected interests, such as the legal guarantee to a fair trial, particularly as regards the presumption of innocence, may occur.

Representatives of the younger generation of lawyers, particularly in Western Europe, often do not realize that a few decades ago, quite seriously, disputes took place under a strange slogan: who is more important - a lawyer or an economist? In a socialist economy, the problem was politically significant as - to use Karl Marx's terminology - the economy formed part of the social basis and law was merely a part of the ideological superstructure.

Speaking seriously however, it is hard to ignore potential conflicts that may occur between law and economics, especially in the context of free market economy and European integration and in the face of progressing globalization. Today however, no one treats it as a strong 
disjunction "either-or" and a completely new methodology of discussion in this area of hard cases has been developed. The fact that a new theoretical-legal trend has evolved, known as so called law and economics analysis, may be regarded as a sign of overcoming this type of - in fact, false - dichotomy. The unquestionable advantage of this modern approach is that lawyers and economists ceased to compete with each other and saw the possibilities of creative collaboration.

This does not alter the fact, however, that at least two fundamental questions remain concerning the conflict between law and economics. The first concerns the economic factors of the legislative fiat - should a legislator, in adopting a decision, take into consideration its economic effects, or may these be arbitrarily disregarded? The second, in turn, is a question of limits - on the one hand, of economic determinism and, on the other hand, the autonomy of law.

Writing about another "enemy" of law, we encountered a problem similar to the aforementioned whilst considering the antagonism which occurs at the borderline between law and science. In fact, this is not so much a direct conflict between law and issues of environmental protection but, rather, the rationality of settling dilemmas arising on the line ecology-economy-science-politics via the use of legal instruments. Therefore, hard cases in this area consist mainly in the need facing a legislator or authority applying the law to balance or choose between different, sometimes difficult to reconcile, arguments which are often non-legal in character. Concurrently, they must remember to adopt a decision which is in accordance with the norms binding in that system of law, whereas the latter is not always internally consistent and coherent.

A lawyer encounters extremely important ethical dilemmas not only in connection with the clash between law and morality but also on the grounds of professional ethics. Nowadays, virtually every professional corporation within a very broad scope of legal professions has its own code of ethics - not only judges, attorneys, legal advisers, prosecutors, notaries, bailiffs, civil servants or government advisers but even law students and academics. There may be found problems common to all of these professional groups but also specific dilemmas connected with not only practicing as a lawyer but also representing certain attitudes and moral views within each of these. For the sake of accuracy, it should be added that this includes both ethical norms and pragmatic rules of professionalism. 
In our view, two examples, which seem to be particularly important and spectacular, and similuatenously fall within the methodological assumptions of hard cases adopted in this article, should be mentioned.

The first concerns problems connected with the relatively little-known in Poland ethics of government advisors. Here we enter the sphere of professional ethics in a very special situation wherein a lawyer is mandatory of a state. This is not a standard lawyer-client relationship because the effects of faulty interpretation or even instrumentalization of law may transpire to be disastrous not merely for an individual but on a global scale. The exceptional moral, political, legal and social responsibility which should accompany this particular form of legal "services" must be stressed. The basic dilemma is inherent in the answer to the following question: Should a government advisor tell his specific client mainly what he expects and what he wants to hear, or merely that which is in accordance with the law? The best exemplification of the subject problem is the controversy around the now famous Torture Papers.

The second example is more standard, not to say classic, in character and concerns practicing as a lawyer. The degree of moral responsibility is also very high in this case, but it relates to a sphere other than government advisor's activity. The most commonly encountered problem concerns the permissible limits of a defense lawyer's activity in a criminal trial. It concerns the standards determined, on the one hand, by the law and, on the other hand, by the principles of legal ethics. The issue raises a number of questions which may only partly be discussed here. Among these, the most important seems to be the question concerning falsehoods deployed by a lawyer, i.e. can a lawyer himself tell lies, and also can he urge his client to tell lies? Then, should a lawyer as a defense lawyer in a criminal trial be objective? Should it be a defense "at any cost" or are there limits which must not be crossed (exceeded) even by a lawyer in the interest of his client? If, and when, may a lawyer refuse to accept a case? If, and under which circumstances, should he renounce a previously accepted power of attorney and relinquish the role of defender? As has been noted, this forms merely part of a difficult series of questions which may and should be posed by a lawyer acting as a defense lawyer in a criminal trial - being aware that, although not all, certainly some are hard cases and require application of Kant's practical reasoning. 
Initially, when we began this study whose stated main purpose is to demonstrate the practical aspects of legal philosophy, we merely intended to discuss a few classic areas where hard cases occur. They were to concern mainly the relationships of law-law, law-morality, law-morals or law-politics. However, whilst writing this article, we began to notice new fields in which law fiercely clashes with other normative systems. This was how the two last cases appeared, namely the assertion that law may conflict with common sense and the individual.

In general philosophy the notion of common sense is usually associated with the so called Scottish Enlightenment and the name of Thomas Reid, but it must be stressed that it has a much longer and rather ambiguous history. Suffice to say, Aristotle was referring to common sense with great respect whilst Plato did so with great contempt. In contrast, legal philosophers have devoted relatively little attention to the problem and a rise of modern discursive-argumentative trends (e.g. J. Habermas, R. Alexy) may be considered as groundbreaking in this negative tradition. Yet it should not be ignored that in the process of applying and interpreting the law as a highly formalized existence conflicts with common sense may sometimes occur. A typical example of this may be found in rules governing the admissibility of evidence in judicial proceedings ${ }^{43}$.

The last example to which we wish to draw the reader's attention became, in our opinion, a conflict raising the hardest case - namely a widely discussed issue concerning torture. The exceptional difficulty of this case is manifested in four basic aspects: 1) in the science of law in general and in the philosophy of law in particular, this issue is most widely and most fervently discussed nowadays; 2) virtually all previously mentioned dimensions of law - creation, application, interpretation, binding and compliance with it - focused on this topic; 3) it concerns a problem which yesterday was recognized as belonging to indisputable imponderables; 4) if the law is to serve primarily an individual, the highest value - the individual's inherent dignity - is put, not without reason, on the line of the debate.

43 See E. Borgida (ed.), Beyond Common Sense. Psychological Science in the Courtroom, Blackwell Publishing 2007. 
All of the above-cited cases lead to the question which, in fact, has been "tormenting" theorists of law for centuries, i.e. what is actually law in its essence? Is it merely a tool which, in the skilled hands of a "social engineer", is capable of resolving every, even the most complicated, hard case? Or perhaps it constitutes merely part of the open, and therefore imperfect, humanities that is condemned to reality per fas et nefas? What actually is the ultimate purpose of law - the efficient management of the system, or the good of an individual?

Accordingly, what is the relevance of hard cases? Do hard cases create bad law, or perhaps on the contrary - in the face of practical discourse help to shape a good, wise and responsible lawyer? And what should be the role of the practical mind - ergo the philosophy of law - in a lawyer's professional life? Where does its role as a medium necessary for every system of law of axiology end and become an unnecessary or even dangerous burden hindering the process of applying law and occasionally leading to interpretation contra legem?

Oliver Wendell Holmes, a famous judge and one of the founders of American legal realism, in his separate opinion in the U.S. Supreme Court judgment in the case of Northern Securities Co v. United States of 1904, wrote that "great cases, like hard cases, make bad law". In American jurisprudence, the sentence has been quoted so often that it may be regarded as a kind of legal topic. Holmes's statement that hard cases, being the object of our interest, make bad law, had however, certain meaning hic et nunc - it was associated with acknowledging that the essence of common law is that, first, the judge decides a particular case and only later, on that basis, attempts to decipher a principle. Cases which were, on the one hand, great and spectacular, and morally and politically complex on the other hand, made bad law because they were atypical - principles created on their basis referred to extreme situations and extended beyond the standards and needs of current legal procedure. Holmes's statement may also be associated with the danger indicated above by J. Stelmach and B. Brożek - of "overproduction" of exceptions to the rules by regulations ${ }^{44}$.

Nowadays it is increasingly common for Holmes's argument to either be recalled in the context of complex ethical, political and legal

44 J. Stelmach, B. Brożek, op. cit., passim. 
issues, or to be subjected to substantial revision ${ }^{45}$. Or perhaps it is just the opposite, perhaps the hard cases make good judges ${ }^{46}$, or even broader - good lawyers? Ultimately, it is only worth stating that hard cases indicate the teaching value of this part of law which is a function of the practical mind in Immanuel Kant's meaning. We assume, after D. v. der Pfordten ${ }^{47}$, that legal philosophy in its broad meaning includes, on the one hand, the theory of law (theoretical analyzing, generalizing and systematizing mind) and, on the other hand, the ethics of law (practical critical mind). Therefore, with some simplification, it may be said that the theory of law from this perspective analyzes, generalizes and systematizes the law as it is; whilst the ethics of law criticizes it in reference to the law as it should be, from the perspective of a certain ideal of law. In deciding hard cases, the theory of law is no longer sufficient for a lawyer, he must appeal to his practical mind, ergo - to the philosophy of law sensu largo. For the purposes of this study it is assumed, as in Polish literature by for example M. Zirk-Sadowski, that the philosophy of law may be practiced "from philosophy to law" or "from law to philosophy" ${ }^{\text {. When deciding }}$ hard cases, the second model is applied.

A well-known contemporary theorist of law G. Teubner often refers in his works to the following anecdote:

"An elderly Bedouin sheikh drew up his will. The whole wealth - a huge herd of camels - was divided among three sons. Achmed, the eldest, was to inherit half of it; Ali, the younger was to get a fourth part of it; and the sixth part should be given to the youngest, Benjamin. After the sheikh's death it turned out that there were only eleven camels in the herd. Achmed demanded six camels and it was opposed by his brothers. Unable to reach an agreement, the sheikh's sons asked the Caliph. He decided as follows: 'I will give you one of my camels. Give it back to me, for Allah sake, as soon as possible'. Dividing the herd of twelve camels was not difficult.

45 F. Schauer, Do Cases Make Bad Law?, The University of Chicago Law Review, 2006, Vol. 73, No. 3, at pp. 883-918.

46 S. Sherry, Hard Cases Make Good Judges, Northwestern University Law Review, 2004, Vol. 99, No. 3, at pp. 3-31.

47 D. v. der Pfordten, Was ist und wozu Rechtsphilosophie?, in: Juristenzeitung 2004, Vol. 4, No. 1, at pp. 157-166.

48 M. Zirk-Sadowski, Wrowadzenie do filozofii prawa, Kantor Wydawniczy Zakamycze, Zakamycze 2000. 
Achmed got his half, six camels. Ali received his fourth, three camels. Benjamin inherited the sixth part, that was two camels. Happy brothers fed the twelfth camel, which was left after dividing the herd, and gave it back to the Caliph" ${ }^{\prime 9}$.

For the law and lawyers, very different morals may be drawn from this tale. From the point of view of the main subject of this study we would like to point out the following: the work of any lawyer, both theorist and practitioner, consists in searching for the twelfth camel. The law in the sense of positive law is often not perfect and we are faced with the need to find a certain "surplus" (ius) enabling rational and correct decisions. Sometimes, when the norm is unambiguous and the facts do not give rise to doubts, the process of searching for the twelfth camel is relatively easy. In practice, especially where law comes into contact with other normative systems, hard case may be found. From the point of view of the definition of hard cases adopted herein, the collision between lex and ius may occur not only in the process of applying and interpreting law but also in relation to its creation, binding and compliance therewith. This "Caliph" who lends us the twelfth camel (ius) thus enabling decision in legal equation (lex) exemplifies a broadly understood idea of law which is expressed in the harmony of three elements: security, usefulness and justice.

Hard cases show that there is an inherent relationship between ius and lex - ius without lex appears to be helpless; and in turn lex without ius is often callous. A little perversely perhaps, because at the end of this article, we would like to pose some questions and ask the reader for a moment of reflection: What exactly is the relationship between law and humanities in its broad sense $?^{50}$ What exactly is law: also a part of humane culture, or merely a tool of social engineering? ${ }^{21}$ Are the problems forming the basis for hard cases merely taboo that can be overcome or perhaps an archetype we do not wish to undermine? And finally, do hard

49 G. Teubner, Sprawiedliwość alienująca. O dodatkowej wartości dwunastego wielbłąda, Ius et Lex 2002, No. 1, at p. 109 et seq.

50 J.M. Balkin, S. Levinson, Law and Humanities: An Uneasy Relationship, Yale Journal of Law \& Humanities, 2006, Vol. 18, No. 2, at pp. 155-187.

51 D. Howarth, Is Law a Humanity (or is it more like Engineering)?, Arts \& Humanities in Higher Education, 2004, Vol. 3, No. 1, at pp. 9-28. 
cases in fact make bad law or may it be vice versa that hard cases make good lawyers? It is difficult to disagree with the opinion of the well-known Australian judge M. Kirby that "to judge is to learn" and therefore "formalism and a purely mechanical approach to performing the function of a judge makes it impossible to perform the real role of a judge" ${ }^{2}$.

As an example of the hardest case from the arena of international law, we propose to consider the problem of humanitarian intervention. In recent years we have observed global debate on this issue. This phenomenon is closely related to some international and very tragic events: Gulf War, Somalia, Rwanda, Bosnia, Haiti, Sierra Leone, Kosovo, East Timor, Afghanistan, Iraq etc. The concept of humanitarian intervention has become an important moral, political and legal (quasi-legal? illegal?) instrument in the international campaign for the protection of human rights. However, this institution is not merely one of the most controversial issues in public international law but has also some important philosophical aspects, some of which this article explores. We may compare the legal, political and ethical aspects of humanitarian intervention with similar problems that accompany another legal institutions, political problems and philosophical topics: e.g. just or unjust war, universality or particularity of human rights, impunity or universal jurisdiction, legality or legitimacy, argument from justice or injustice and - last but not least - legal positivism or natural law on international level.

In the worldwide debate about human rights, two trends have been predominant in recent years: the question of the universality of human rights and individual freedoms and the issue of legality and legitimacy of humanitarian intervention ${ }^{53}$. From the point of view of both philosophy of law in general, and dogmatics of international law in particular, these issues have a distinct nature but, on the other hand, their common elements may not be ignored ${ }^{54}$. To simplify, it may be said that advocates

52 M. Kirby, To Judge Is to Learn, Harvard International Law Journal, 2007, Vol. 48, No. 1 , at p. 36 .

53 P.R. Baehr, Controversies in the Current International Human Rights Debate, Human Rights Working Papers 2000, No. 3, http://www.du.edu/humanrights/workingpapers/ index.html.

54 F.K. Abiew, The Evolution of the Doctrine of Humanitarian Intervention, The Hague-Boston-London 1999, at pp. 83-90. He draws attention to the connection between the universality of human rights and humanitarian intervention. 
of the universality of human rights tend to be ex definitione more in favour of humanitarian intervention than their opponents who argue for cultural pluralism. And conversely - protagonists of humanitarian intervention ex definitione seek arguments for its legality and legitimacy on the basis of moral universality rather than on the grounds of relativism.

Heated debate concerning the universality of human rights started in the world science in the 1980s and reached their culmination in the mid-1990s, especially during the Human Rights Conference in Vienna in 1993, and mainly in connection with so-called Asian values. The debate concerning the nature of human rights has dominated most present-day intellectual debates i.e. in political philosophy - between liberalism and communitarianism, in philosophy of law - between positivism and non-positivism, in ethics - between universality and relativism. Almost all eminent ethicists, philosophers, political analysts, lawyers and sociologists have participated in these debates: R. Alexy, Ph. Alston, N. Chomsky, J. Donnely, F. Fukuyama, J. Galtung, A. Gutman, J. Habermas, R. Howard, O. Hoffe, S Huntington, A. McIntyre, W. Kersting, M. Nussbaum, J. Rawls, R. Rorty, M. Sandel, A. Sen, Ch. Taylor or M. Waltzer, to name only a few. It is characteristic that most of these authorities ${ }^{55}$ have recently also expressed their opinion on humanitarian intervention, which confirms its relationship with the universality of human rights. The aforementioned names bespeak, not only formally, that the problem is of great significance, and that the manner in which it is resolved may have far-reaching practical consequences. There is one more characteristic of the exemplary enumeration - I have only mentioned thinkers representing Western culture (or at least related thereto), while the debate on the universality of human rights is an inter-civilization debate and scientists from the Islamic world, Subsaharian Africa or the Far East have actively participated. This fact makes the problem even more complex, since

55 Compare for example J. Donnely, Genocide and Humanitarian Intervention, Journal of Human Rights 2002, Vol. I, No. 1, at pp. 93-109; J. Habermas, Bestialität und Humanität. Ein Krieg an der Grenze zwischen Recht und Moral, in: R. Merkel (ed.), Der Kosovo-Kried und das Volkerrecht', Frankfurt a. Main 2000, at pp. 51-65; O. Hoffe, Humanitare Intervention?, [in:] D.S. Lutz (ed.), ,Der Kosovo-Krieg. Rechtliche und rechtsethische Aspekte', Baden-Baden 1999/2000, at pp. 233-236; W. Kersting, Politik und Recht, Weilerwist 2000, at pp. 237-272; M. Waltzer, The Argument about Humanitarian Intervention, Dissent, Winter 2002, at pp. 29-37. 
there is no unanimity concerning the approach or even acceptance of the universality of human rights at an intercultural level but also within seemingly homogenic Western thinking. According to Habermas, this intellectual debate is not only taking place at an inter-civilization level but is also a debate involving "the West with itself"

In recent years, this worldwide debate has lost its initial impetus ${ }^{57}$ in consequence of September 11 terrorists attacks and declaration of war on terrorism. Subtle philosophical ponderings on either the universality or relativism of human rights have been eclipsed by the question of legality and legitimacy of humanitarian intervention undertaken with the aim of stopping massive human rights violations. In literature, the treatment of the relationship between the war on terrorism and humanitarian intervention is not unequivocal. On the one hand, there are attempts to draw parallels between preventive war and humanitarian intervention on the grounds of the tradition of so-called just war; on the other hand, a question arising with increasing frequency is whether or not the war on terrorism means the end of an era of "pure" humanitarian intervention as humanitarian motives are superseded with strategic national and international security targets (vide: Afghanistan, Iraq) ${ }^{58}$.

Although the debate on humanitarian intervention started earlier than arguments concerning its universality, it may be dated back to the $1970 s^{59}$ in connection with several armed attacks at that time (i.e. especially in Eastern Pakistan/Bangladesh), but in both cases it evolved into two different directions. After 1945, particularly following

56 J. Habermas, Zur Legitimation durch Menscherechte, in: H. Brunkhorst, P. Niesen (eds.), Das Recht der Republik', Frankfurt a. Main 1999, at p. 386.

57 In spite of this the issue of universality of human rights is in the focus of interest of science - of recent works on the subject especially extensive monograph of E. Brems, Human Rights: Universality and Diversity, The Hague-Boston-London 2001.

58 Compare G.R. Lucas, The Role of "International Community" in Just War Tradition - confronting the Challenges of Humanitarian Intervention and Preemptive War, Journal of Military Ethics 2003, Vol. 2, No. 2, at pp. 122-144 and Sung-han Kim, The End of Humanitarian Intervention?, Orbis - A Journal of World Affairs, Fall 2003, at pp. 721-736.

59 Of the works of the time especially R. B. Lillich, Humanitarian Intervention and the United Nations, Charlottesville: University Press of Virginia 1973; some time later it was published the classic work edited by the prominent representative of so-called English school of international relations H. Bull, Intervention in World Politics, Clarendon Press, Oxford 1984. 
the adoption of the Universal Human Rights Declaration in 1948, the universal character of basic rights and freedoms of individuals was accepted a priori and the debate in world literature of the 1980s-1990s sought to impair, or at least make the postulates of universality more relative. As regards the debate concerning humanitarian intervention, a different situation is perceptible. Article 2(7) of the UN Charter initially excluded, also to some extent a priori, the possibility of applying humanitarian intervention as a means for resolving conflicts, whether international or internal. The only two exceptions concerning the threat or use of force in international relations are either cases of self-defense or actions which enjoy UN Security Council authorization according to the procedure laid down in Chapter VII of the UN Charter in cases of threats to world peace and security. UN Security Council authorization following the procedure of declaration "Uniting for Peace" might be recognized as a third exception. These exceptions, however, did not initially assume the use of force with regard to humanitarian intervention in the present meaning of the institution, at least due to a relatively wide interpretation of the so-called internal authority of the state resulting from Article 2(7) of the UN Charter. However, international practice went in other direction - in the 1960s and $1970 s^{60}$, episodes of intervention in internal conflicts occurred which may be recognized as humanitarian interventions from today's perspective and standpoint, even if the interveners referred to the notion of self-defense as opposed to humanitarian reasons ${ }^{61}$ (i.e. India's intervention in East Pakistan, or to some extent Tanzania's intervention in Uganda and Vietnam's in Cambodia). As the system of international

60 F.K. Abiew, op. cit., at pp. 102-131; S. Chesterman, Just War or Just Peace? Humanitarian Intervention and International Law, Oxford University Press 2002, at pp. 63-83; S. Murphy, Humanitarian Intervention. The United Nations in an Evolving World Order, University of Pennsylvania Press, Philadelphia 1996, at pp. 83-115; N. Wheeler, Saving Strangers. Humanitarian Intervention in International Society, Oxford University Press 2002, at pp. 55-136.

61 An interesting attempt of considering the problem of use of force in international relations from the point of view of self-defense was made recently by T.M. Franck. Within the accepted classification the author recognizes, among others, also the cases of so-called 'purely humanitarian intervention' as for instance interventions in Bangladesh, Uganda, Cambodia, Central Africa, Iraq (1991), Sierra Leone and Kosovo - T.M. Franck, Resource to Force. State Action Against Threats and Armed Attacks, Cambridge University Press 2002, at pp. 135-173. 
protection of human rights has evolved, the approach to the internal competence of the state in interpreting the above-quoted rule of the UN Charter changed. The process intensified in the 1990s following the fall of the communist system and the end of Cold $\mathrm{War}^{62}$ and at the same time humanitarian motives for intervention appeared more regularly. From this point of view, NATO's intervention in Kosovo was a turning point - both the legality and legitimacy of this action have been the subject of debate until the present day ${ }^{63}$. The conclusion to the report of the International Commission on Kosovo offers the best example of this. It reads, "[t]he Commission acknowledges that the NATO's military intervention was illegal, though legitimate". And further it goes on to state: "[t]he lesson from NATO's intervention in Kosovo shows that there is a need to bridge a gap between legality and legitimation" ${ }^{24}$. The conflict between legality and legitimacy is not a new question for lawyers and it has always been the main subject of philosophical and juridical debates. It was defined in a very explicit way by Radbruch in his conception of the antimony between three elements of the idea of law: security, purposefulness and justice $^{65}$. Never before has it been so intense in the theory and practice of international law as it is now because never before has the dogma of unlimited state sovereignty in international relations been questioned on the strength of the arguments ensuing from the system of international human rights protection. It obviously does not mean that the ideal balance between resolving the potential conflict between state sovereignty and international legal commitments concerning protection of human

62 F.K. Abiew, op. cit., at pp. 137-222; S. Chesterman, op. cit., at pp. 127-162; S. Murphy, op. cit., at pp. 145-281; N.J. Wheeler, op. cit., at pp. 139-284.

63 Compare for example G. Beestermoller (ed.), Die Humanitare Intervention - Imperativ der Menschenrechtsidee? Rechtsethische Reflexionen am Beispiel des Kosovo-Krieges, Stuttgart 2003; J.L. Holzgrefe, R.O. Keohane (eds.), Humanitarian Intervention. Ethical, Legal and Political Dilemmas, Cambridge University Press 2003.

64 The Independent International Commission on Kosovo, The Kosovo Report. Conflict, International Response, Lessons Learned, Oxford University Press 2000, at p. 4 and 10.

65 The fact that the conception comes from Radbruch is not surprising as the problem of legality and legitimation was widely discussed in German legal science during the Weimar Republic - compare more recent D. Dyzenhaus, Legality and Legitimacy - Carl Schmitt, Hans Keisen, and Hermann Heller in Weimar, Oxford University Press 1999 and A.J. Jacobson, B. Schlink (eds.), Weimar. Jurisprudence of Crisis, University of California Press 2000. 
rights has been found - merely that the importance of the problem has been recognized ${ }^{66}$. This is apparent in the attitude towards the post of UN Secretary-General in recent years. In 1991 Cuellar stated that "the rule of not interfering in states internal jurisdiction cannot be a protection barrier behind which human rights could be violated on a massive or systematic scale with impunity" ${ }^{67}$. His successor, Boutros Ghali, in "Agenda for Peace" of $1992^{68}$, stressed that state sovereignty and territorial integrity still form the basis of international relations but at the same time he added that "the time of absolute and exclusive sovereignty has passed". The turning point in the process of recognizing the issue was the speech of the UN Secretary-General, Kofi Annan, of 20 September 1999 to UN General Assembly: "[t]he state sovereignty is being re-defined by globalization and international co-operation powers. It is widely understood that the state should serve its citizens and not vice versa" ${ }^{69}$.

Radbruch suggested that the potential conflict between legal security, purposefulness and justice should be resolved in favorem of the former unless the injustice of a legal norm is so unbearable that the foul law should be replaced by the rule of justice itself. In fact, this may be applied to cases when procedural deficiency resulting from definitions in the UN Charter causes the international community to remain inactive, witnessing massive human rights abuses, or even genocide, war crimes and crimes against humanity. The problem of humanitarian intervention is the extreme normative exception, so it may be perceived as a conveyance of so-called Radbruch formula into international relations.

The war in Kosovo was in itself a special case due to the character of military actions and the unclear position of the UN Security Council, yet at the same time, it became a pretext for attempts to reinterpret

66 Compare for example G.M. Lyons, M. Mastanduno (eds.), Beyond Westphalia? State Sovereignty and International Intervention, The John Hopkins University Press, Baltimore London 1995.

67 Quotation of K. Annar, Peacekeeping, Military Intervention, and National Sovereignty in Internal Armed Conflict, [in:] J. Moore (ed.), 'Hard Choices. Moral Dilemmas in Humanitarian Intervention', Rowman \& Littlefield Publishers, Oxford 1998, p. 58.

68 Agenda for Peace. Preventive Diplomacy, Peacemaking and Peacekeping, point 17 - available at: http://www.un.org./Docs/SG/agpeace.html.

69 United Nations Press Release SG/SM/7136/GA/9596 - available at: http://www. un.org./News/Press/docs/1999/19990920.sgsm7136.html. 
previously existing attitudes concerning both the interdiction on the threat or use of force in international relations (Art. 2(4) of the UN Charter) and the principle of non-intervention in internal affairs of other state (Art. 2(7) of the UN Charter). It also worked as a stimulus to reflection on the role and future of the Security Council, or even the whole system of United Nations ${ }^{70}$. As a result, since 1999 the number of scientific papers concerning humanitarian intervention has considerably risen and essentially there are now more proponents of the institution, although they give various and different justifications for their approval of the possibility of military intervention designed to prevent or end massive violations of human rights ${ }^{71}$.

The need for a new approach to legality and legitimation of humanitarian intervention was noticed in the mid-1990s, for example by Ramsbotham and Woodhouse who, in 1996, attempted to "reconceptualize" the institution by comparing intervention in Uganda with conflicts in Iraq, Bosnia and Somalia ${ }^{72}$. It must be underlined that the quest for an increasingly rational for resolve conflicts between state sovereignty and norms of international human rights protection continues to the present

70 Proposals have been made for reforms of the system from the point of view of humanitarian intervention, including even the change of the UN Charter - compare for instance M. Ayoob, Humanitarian Intervention and International Society, Global Governance - a review of Multilateralism and International Organization, Vol. 7, No. 3 July-September 2001; see also the debate of various authors on these proposals in The International Journal of Human Rights 2002, Vol. 6, No. 1, Forum: Humanitarian Intervention, at p. 79 and especially M. Ayoob, Humanitarian Intervention and State Sovereignty, at pp. 81-102 and N.J. Wheeler, Decision-making Rules and Procedures for Humanitarian Intervention, at pp. 127-138. On possibilities and limitations of structural and procedural reform of the UN Security council also in T.G. Weiss, The Illusion of UN Security Council Reform, The Washington Quaterly Autumn 2003, Vol. 26, No. 4, at pp. 147-161.

71 In literature it was clearly shown on the example of the war in Kosovo - extreme attitudes are represented: from the attempts of justification of legality of humanitarian intervention (see M. Brenfors, M.M. Petersen, The Legality of Unilateral Humanitarian Intervention - A Defence, Nordic Journal of International Law 2000, Vol. 69, No. 4, at pp. 449-499), to recognizing NATO's action as crime against humanity (M. Cohn, NATO Bombing of Kosovo: Humanitarian Intervention or Crime Against Humanity?, International Journal for the Semiotics of Law 2002, Vol. 15, No. 2, at pp. 79-106).

72 O. Ramsbotham, T. Woodhouse, Humanitarian Intervention in Contemporary Conflict. A reconceptualization, Polity Press, Cambridge (Mass.) 1996. 
day. In contemporary literature, opinions stressing the necessity to rethink humanitarian intervention from ethical, political and legal perspectives is increasingly visible. According to Lepard, it is urgent to work out "the fresh attitude based on ethical foundations of international law"73. To a certain extent, the Report of the International Commission on Intervention and State Sovereignty (ICISS) of 2000, created under the aegis of the Canadian government, may serve as an example of such attitude. The document explicitly points not only to the urgent need for a legal-international definition of humanitarian intervention and the conditions for its legality, legitimation and operational efficacy, but also places it against a background of strategies of contemporary international relations. It is very characteristic for the document that its authors suggest replacing the term "humanitarian intervention" with the notion "responsibility to protect" ${ }^{\text {". }}$. The problem is not only when, under which conditions, and in what manner to intervene, but also how to prevent humanitarian crises and how to maintain peace after a military conflict and rebuild democratic, stable social structures and economic infrastructure. The concept of responsibility to protect is threefold: the responsibility to prevent, the responsibility to react and the responsibility to rebuild ${ }^{75}$.

In his above-mentioned speech of 20.9.1999, Kofi Annan suggested that the notion of humanitarian intervention should be understood extremely widely and that it should cover actions "from the most peaceful to the most forceful". In fact, if the character of such interventions is taken seriously, situations when non-military and "purely" humanitarian methods, such as supply of food, medicines, medical aid are applied, they cannot be ignored. From this point of view, intervening subjects may be not only states but also non-governmental organizations. One may also not neglect situations when the intervention has a military character but is undertaken at the request of the country in question which is unable

73 B.D. Lepard, Rethinking Humanitarian Intervention, the Pennsylvania University Press 2002; compare also recently A. Oxford, Reading Humanitarian Intervention. Human Rights and the Use of Force in International Law, Cambridge University Press 2003 - while Lepard approves such redefined humanitarian intervention, Orford is rather critical in her opinion taking as the starting point the intervention in East Timor.

${ }^{74}$ Report of the International Commission on Intervention and State Sovereignty. The Responsibility to Protect, Canada, December 2001.

75 Ibidem, at pp. 19-46. 
to resolve serious internal problems. Finally, the theory and practice of international law distinguishes two situations: when intervention is aimed at protecting its own citizens in another state's territory, and when it is aimed at protecting citizens other than its own. In this respect, there has been a reasonable evolution of the institution of humanitarian intervention. While nineteenth-century practice ${ }^{76}$ shows the prevalence of the former, being a cover for colonial and religious motives, according to Wheeler present-day interventionism is aimed mainly at "saving strangers"77. In recent years, however, instances of the first type of intervention have occurred (to a certain extent American intervention in Grenada in 1983 or Panama in 1989 could be recognized as such) but in literature they are named as intervention d'humanite and they are distinguished from humanitarian intervention sensu stricto $^{78}$.

From this standpoint, there is an internal semantic inconsistency when it comes to the term "humanitarian intervention". If we say intervention - then not humanitarian but military and forced, and if humanitarian - then not intervention but aid. In the doctrine of international law we have a rather opposite trend, since a certain paradigm has already been fixed and most authors limit their definitions only to actions of military and forced character, determined by the humanitarian motives and aims of the intervening state, group of states or international organization without the permission of the state within whose territory such intervention occurs. There are also two main criteria for dividing the instances following 1945 that have been classified as humanitarian intervention. The first is chronological in character and its turning point is the end of Cold War - in literature there is a clear distinction between interventions which took place in the 1960s and 1970s (e.g. Congo, Dominican Republic, East Pakistan, Uganda, Cambodia) and those in the 1990s (e.g. Iraq, Somalia, former Yugoslavia, Rwanda, Liberia, Haiti). As a result, this classification, though based on a formal time criterion, has very clear political dimension. The second criterion,

76 On the subject of nineteenth-century interventionism see W. Grewe, Epochen der Volkerrechtsgeschichte, Baden-Baden 1984, at pp. 573-583.

77 N.J. Wheeler, supra note 61.

78 R. Kolb, Note on Humanitarian Intervention, International Review of the Red Cross, No. 849 of 31.03.2003, at p. 120. 
from the point of view of international law, is of a much more serious character. In this case, interventions are divided into those which enjoyed UN Security Council authorization ex ante (e.g. Iraq, Rwanda, Somalia) and those which were undertaken without such authorization (e.g. Kosovo), even if such consent was tacit (e.g. Central Africa, Tanzania) or clear (e.g. Liberia) ex post factum $^{79}$. This classification is, in turn, formal-legal in character and is based on the existence or absence of the UN Security Council resolution, but it results in the material-legal application and interpretation of the UN Charter. It must be said that both criteria - of the end of Cold War and of the UN authorization - in spite of appearances, are closely related to each other, since the demise of the communist system raised hopes for the end of paralysis of the Security Council in authorizing humanitarian interventions ${ }^{80}$. Even if the 1990s to a certain extent disappointed these hopes ${ }^{81}$, the authors of the above-mentioned ICISS Report remain right in their conclusion which appeals for an informal pact allowing superpowers to act in dubio pro humanitate, at least in cases of flagrant humanitarian crises which pose a threat to world peace and security ${ }^{82}$.

It is clearly perceptible that the issue of humanitarian intervention cannot be treated per non est. It also cannot be considered in a selective and one-dimensional way - from the point of view of either: ethics, politics or law ${ }^{83}$. It is a phenomenon whose understanding and resolution

79 Danish Institute of International Affairs, Humanitarian Intervention. Legal and Political Aspects, Copenhagen, DUPI 1999, at pp. 57-95 - available at: <http://www.dupi. $\mathrm{dk} / \mathrm{fmp} 4.0 /$ web/en1224.html .

80 More on the subject see R.-J. Dupuy (ed.), The Development of the Role of the Security Council, Martinus Nijhoff Publishers, Dordrecht-Boston-London 1993.

81 On the other hand it must be admitted that in the 1990s there was a considerable increase of Security Council engagement in realization of the United Nations aims concerning human rights protection resulting from the UN Charter and especially in the context of humanitarian intervention - for more see B.G. Ramacharan, The Security Council and the Protection of Human Rights, The Hague-London-New York 2002; L. Henkin, G.L. Neuman, D.F. Orentlicher, D.W. Leebron (eds.), Human Rights, New York 1999, at pp. 707-737; Ph. Alston, H.J. Steiner, International Human Rights in Context, 2. Oxford University Press 2000, at pp. 648-694.

82 Report of the International Commission, op. cit., at p. XIII and 75.

83 Recently the attention is drawn by authors of works in J.L. Holzgrefe, R.O. Keohane (eds.), op. cit. 
requires all three perspectives to be taken into consideration ${ }^{84}$. Moreover, on each of these three planes very complicated theoretical and practical problems emerge, and consequently only a holistic approach ${ }^{85}$ makes it possible to elaborate a position free of internal contradictions. The issue of humanitarian intervention can be considered only from the standpoint of an extremely positivistic interpretation of the UN Charter, particularly Article 2(4) in connection with Article 2(7). In the theory of law in general, and in the theory of international law in particular, such a position in the past, especially in context of the evolution of the theory of human rights, that in a sense ex definitione is a "non-positivistic" theory which does not have to mean "legal-natural" at the same time. Obviously, the other question is whether such "non-positivism" provides an efficacious solution to all ethical, legal and political dilemmas connected with humanitarian intervention. The matter is, however, of a different nature. Present debate on humanitarian intervention reflects only a wider tendency in legal science, i.e. withdrawal from traditional legal "passivism" and a move towards legal "activism" which better meets modern requirements. In international law it means a withdrawal from traditional "statism" with states being the sole focus of interest, whilst the subjective interests of individuals are overlooked ${ }^{86}$. The presence or absence of a legal justification for humanitarian intervention must have ethical and political foundations. Without ethical legitimation, humanitarian intervention may be perceived as a law of the stronger or a new form of colonialism. Conversely, without political legitimation the debate may be reduced to empty moralism ${ }^{87}$.

84 It seems to be necessary to expand the debate to ethical discussion as previous attempts of solving the problem only on political or legal planes have not brought satisfying results - M.J. Smith, Humanitarian Intervention: An Overview of the Ethical Issues, [in:] J.H. Rosenthal (ed.), 'Ethics and International Affairs', Georgetown University Press, Washington D.C. 1999, at p. 279.

85 In the context of the relation between humanitarian intervention and the problem of universality of human rights it is characteristic that holistic approach is often suggested regarding the latter - compare for example A. Belden Fields, Rethinking Human Rights for the New Millenium, Palgrave MacMillan, New York esp. at pp. 73-99.

86 F. Tesón, A Philosophy of International Law, Westview Press, Colorado 1998, esp. at p. 39.

87 It concerns also the issue of universality of human rights - R.A. Falk, Human Rights Horizons. The Pursuit of Justice in Globalizing World, New York-London 2000, at p. 4 . 
Otherwise it is difficult to explain why humanitarian interventions are currently selective and why they have not been undertaken in Chechnya or Tibet. The answer to this question is in fact rhetorical.

Humanitarian intervention concerns values which, in normal conditions, are not contradictory but which, in extreme situations, conflict with each other. These problems may not be resolved by resorting solely to traditional positivism. The war in Kosovo is an example where the dividing line between different positions concerning the attitude of international law to morality is very clear ${ }^{88}$. The conflict between the value of state sovereignty and the value of the international community's responsibility for a universal system of human rights protection is basic from the point of view of the causes of humanitarian intervention. However, the problem may be considered à rebours. It transpires then that, from the standpoint of the course and results, humanitarian intervention may mean the conflict between the value of protecting human rights and the value of peace and interdiction on using force in international relations as the foundations of the present-day international community ${ }^{89}$. In any case, employing the above-mentioned rhetoric of Radbruch's formula transferred to an international level, it may be said that in humanitarian intervention we deal with the conflict between security and order versus justice $^{90}$. The problem concerns not only external forms and the results of the institution but it is inherently embedded in its essence.

88 From this point of view for example S. Schieder divides lawyers of international law into 'legalists' who are in favour of restrictive interpretation of Article 2(4) of the UN Charter and 'moralists' trying to reinterpret the Charter because of the special case of the war in Kosovo, and this moralism can be 'minimalistic' or 'maximalistic' depending on what changes are suggested - S. Schieder, Pragmatism as a Path towards a Discursive and Open Theory of International Law, European Journal of International Law 2000, Vol. 11, No. 3, at p. 691. This division reflects however only the general trend of returning to ethics in contemporary international law and its science - see M. Koskenniemi, 'The Lady Doth Protest Too Much' Kosovo, and the Turn to Ethics in International Law, The Modern Law Review 2002, Vol. 65, No. 2, at pp. 159-175.

89 The attention is drawn by N. Kirsch, Legality, Morality, and the Dilemma of Humanitarian Intervention after Kosovo, European Journal of International Law 2002, Vol. 13, No. 1, at pp. 323-336.

90 Danish Institute of International Affairs, Humanitarian Intervention. Legal and Political Aspects, op. cit., at pp. 14-17; see also N.J. Wheeler, supra note 61, at pp. 11-13. 
Taking into account all of the above-mentioned provisos concerning the notion, types and ethical, political and legal implications of humanitarian intervention, it must be said that in contemporary literature on international law narrow definitions are predominant. a typical example may be S. Murphy's suggestion: "Humanitarian intervention is the threat or use of force by a state or a group of states or an international organization against the other state aiming at protecting its citizens from massive violations of internationally recognized human rights" ${ }^{\prime 1}$. Similar definition can be found in the report of the Danish Institute of International Affairs of 1999:

"For the need of the present report, humanitarian intervention is defined as a coercive action of states with the use of armed forces in other state without the permission of the state government, with or without UN Security Council authorization aiming at averting or stopping massive human rights or international humanitarian law violations"92.

F.K. Abiew suggests that the term should be understood as "coercive measures applied by a state, a group of states, an international organization or humanitarian agencies with the aim (or at least one of the main aims) to end massive human rights violations"93.

Such terminological suggestions are plentiful as contemporary literature on humanitarian intervention is vast ${ }^{94}$. There are very general definitions as, for instance, I. Brownlie's who mentions the threat or use of force aimed at human rights protection ${ }^{95}$. Other authors, such as for example W.D. Verwey, limit the term only to military actions not authorized by the competent UN organs ${ }^{96}$. It must be admitted that the

91 S. Murphy, op. cit., at p. 11.

92 Danish Institute of International Affairs, op. cit., at p. 11.

93 F.K. Abiew, op. cit., at p. 18.

94 See the extensive bibliography in Supplementary Volume to the Report of the International Commission on Intervention and State Sovereignty. The Responsibility to Protect. Research, Bibliography, Background, Canada, December 2001, at pp. 227-336.

95 I. Brownlie, Humanitarian Intervention, [in]: J.N. Moore (ed.), 'Law and Civil War in the Modern World', John Hopkins University Press, Baltimore 1974, at p. 217 - quoted after F.K. Abiew, op. cit., at p. 18.

96 W.D. Verwey, Legality of Humanitarian Intervention after the Cold War,[in:] E. Ferris (ed.), 'The Challenge to Intervene: A New Role of the United Nations?', Life and Peace Institute, Uppsala 1992, at p. 114 - quoted after F.K. Abiew, op. cit., at pp. 12-18. 
latter approach has gained more and more proponents. It is assumed that, presently, the main issue is legality and legitimation of so-called unilateral intervention undertaken without UN Security Council authorization, as so-called collective intervention with the formal approval of UN organs is today unquestionable ${ }^{97}$. The review of all possible approaches, however, would be beyond the limits of this paper. We concentrate only on the attempt to reconstruct certain loci communes characteristic for the phenomenon of humanitarian intervention in present international relations since, despite some differences concerning details amongst individual authors, it is possible to establish a common core of suggestions, which may be reduced to the following five elements ${ }^{98}$.

Firstly, humanitarian intervention means the actual use of force. Some authors also include the threat of force but this is not a universally accepted proposition. In fact, the question is whether the mere threat of using force may be classified as an actual intervention or whether it remains within the limits of widely understood diplomatic means. In this meaning of the term, humanitarian intervention does not extend to cover action not accompanied by military force and confined exclusively to undertaking action with aims and methods that are purely humanitarian, especially when undertaken by non-governmental organizations (NGOs). In the last case, we should refer to humanitarian aid rather than humanitarian intervention. In the first, however, we deal with the use of force or, at least as some claim, with the threat of force.

Secondly, although non-government organizations play an important role during humanitarian intervention their connection to the intervening subject is subsidiary in character. The subject may be an international organization, a state, or a group of states.

Thirdly, the causes of intervention are massive internationally recognized human rights violations in a state within whose borders the intervention takes place. This is a quantitative criterion, since the situation

97 M. Brenfors, M.M. Petersen, op. cit., at p. 450 - and in fact similar M. Wellhausen, Humanitare Intervention. Probleme der Anerkennug des Rechtsinstitus unter besonderer Bercksichtigung des Kosovo-Konflikts, Baden-Baden 2002, at p. 47 and M. Ortega, Military Intervention and the European Union, Institute for Security Studiers Western European Union, Paris 2001, Chaillot Paper no. 45, at pp. 5-17.

98 And also for instance S. Murphy, op. cit., at pp. 12-18. 
should reach a state falling within the definition of a humanitarian disaster (widespread violations of internationally recognized human rights).

Fourthly, the basic aim and motive of actions undertaken by the intervening state is to halt such violations. It is extremely rarely, however, that interventions do not involve other political or economic interests of intervening state. The point is that humanitarian cause should be the primary cause.

Fifthly, in case of humanitarian intervention the aim is to protect nationals of the target state. It may be, however, that citizens of the intervening state are amongst the protected subjects.

Thus formulated, this definition implies the conditions for permissible humanitarian intervention. In the literature on the subject, various criteria for justifying humanitarian intervention are provided. According to N.J. Wheeler ${ }^{99}$, permissibility conditions i.e. legality and legitimation of humanitarian intervention are given in four points: a just cause, which the author suggests calling supreme humanitarian emergency; the last resort; the requirement of proportionality; the likelihood of a positive humanitarian outcome. C.A.J. Coady ${ }^{100}$ supplements this list by defining the appropriate authority to undertake humanitarian intervention and the authors of the above-mentioned ICISS Report also list the need for a proper motive ${ }^{101}$. In this way we have five objective criteria (objective cause, exploration of other possible methods, proportionality of the applied measures, probability of efficiency, humanitarian intentions) and above them subjective criterion (the appropriate authority and only where objective criteria are fulfilled). In connection with the latter there arises the widely encountered argument concerning the issue of a right, or even moral (legal?) duty of humanitarian intervention ${ }^{102}$.

In this context, naturally the most controversial question concerns the subject authorized to undertake humanitarian intervention if substantive premises are met. If this is to be a subject authorized in this way or another by UN organs then what purpose is served by the

99 N.J. Wheeler, supra note 61, at p. 33.

100 C.A.J. Coady, The Ethics of Armed Humanitarian Intervention, United States Institute of Peace, Washington 2002, at pp. 24-31.

101 Report of the International Commission, op. cit., at p. XII.

102 C.A.J. Coady, op. cit., at p. 25. 
pretext for humanitarian intervention, given that the foundation could be a threat to world peace and security? If, in turn, it may be a subject acting without such authorization and not in self-defense then how, on the grounds of the UN Charter, can the legality of such military action be justified? And how does it relate to duties resulting from the system of international human rights protection and resulting in erga omnes? It may be argued, following the ICISS Report, that the best solution is to adhere to the model of collective security formulated in the UN Charter. But what if the system is paralyzed, as has happened in the past, by an unfounded, from the moral point of view, use of the veto by a permanent member of the Security Council? And also vice versa - who can guarantee that bypassing the UN system due to the political paralysis of the UN's basic organs will be in practice not more than a form of pax americana? This objection is often raised with regard to NATO actions in Kosovo and also to the war in Iraq, although the latter can hardly be recognized as an example of classic humanitarian intervention. The fact that Soviet interventions in Hungary, Czechoslovakia or Afghanistan were once considered as an indication of pax sovietica augments the ambivalence of the case ${ }^{103}$. On the other hand, however, the USSR's military interventions in Hungary in 1956 or in Czechoslovakia in 1968 and NATO's action in Kosovo in 1999 can hardly be put on the same plane.

Such questions and doubts are innumerable. At the same time it is difficult to predict in which direction international law will evolve in the future - will it return to a restrictive interpretation of existing norms ${ }^{104}$, will it result in the amendment of the UN Charter, the creation of a new customary legal norm ${ }^{105}$, the reinterpretation of the UN Charter or the creation of a parallel system "bypassing" its regulations ${ }^{106}$, treating each case ad casum in categories of extreme exception, sometimes even at price of legality? ${ }^{107}$ Today each of these solutions, perhaps excluding the latter,

103 Ch. Gray, International Law and the Use of Force, Oxford University Press 2000, at p. 62 .

104 Ibidem, passim.

105 A. D'Amato, There is no Norm of Intervention or Non-Intervention in International Law, International Legal Theory Spring 2001, Vol. 7, No. 1.

106 J.L. Holzgrefe, R.O. Keohane, op. cit., passim.

107 B. Simma, NATO, the UN and the Use of Force: Legal Aspects, European Journal of International Law 1999, Vol. 10, No. 1, at p. 1-22; also commentary A. Cassese, 
seems both controversial and doubtful as regards the possibilities and chances of practical implementation.

It may appear simpler to define the objective rationale of humanitarian intervention, although this is also fraught with theoretical and practical difficulties. Just cause refers to the theory of a just war (bellum justum $)^{108}$, but it is simultaneously distinct from this notion, since it is limited to preventing large scale human rights violations. Naturally, difficulties surround the meaning of "large scale" in this context, but terms such as genocide, crimes against humanity or war crimes, already defined in international law, may be offering some assistance here. Obviously, not every case of human rights violations may jusify humanitarian intervention ${ }^{109}$, only those which result in humanitarian crisis on a disastrous scale.

Similar difficulties relate to the other substantive conditions governing the permissibility of humanitarian intervention. This is best illustrated by considering NATO's intervention in Kosovo. Even the proponents of the intervention admit that, on the one hand, the requirement of proportionality may be impaired as bombings were directed not only at military targets but also caused many civilian casualties and destruction of both the natural environment and economic infrastructure whilst, on the other hand, the principle of last resort may be questioned as it is still not clear if all diplomatic means and procedures provided in the UN Charter had been explored. Doubts

Ex iniuria ius oritur; Are We Moving towards International Legitimation of Forcible Humanitarian Countermeasures in the World Community? and also at p. 23 and recently M. Byres, S. Chesterman, Changing the Rules about the Rules? Unilateral Humanitarian Intervention and the Future of International Law, [in:] J.L. Holzgrefe, R.O. Keohane (eds), op. cit., at pp. 177-203.

108 M. Fixdal, D. Smith, Humanitarian Intervention and Just War, Mershon International Studies Review 1998, Vol. 42, No. 2, at pp. 283-312 - for more see the classic M. Waltzer's work, Just and Unjust Wars: A Moral Argument with Historical Illustrations, $3^{\text {rd }}$ edition, London 2000.

109 For example one of the most agitating problems for the public opinion has been female genital mutilation in some cultures. It is not, however, the reason for humanitarian military intervention but for activities of non-government organizations. A. Treueblood, Female Genitalian Mutilation: A Discussion of International Human Rights Instruments, Cultural Sovereignty and Dominance Theory, Denver Journal of International Law and Policy 2000, Vol. 28, No. 4, at p. 464. 
concerning other permissibility conditions of humanitarian intervention i.e. an appropriate motive and positive humanitarian outcome have been discussed earlier in this article.

As mentioned above, the issue of humanitarian intervention is extremely complex not only from ethical and political perspectives but also (and possibly particularly) from a legal point of view. This cannot mean, however, that we should abandon attempts to resolve such issues at a juridical level. According to the authors of the above-quoted report of Danish Institute of International Affairs ${ }^{110}$ there are four strategies of humanitarian intervention based on the existing international law ${ }^{111}$ :

1) Maintaining the present political-legal status quo on the grounds of the UN Charter and permitting humanitarian intervention only on the basis of UN Security Council authorization following the fulfillment of certain material-legal conditions (the status quo strategy);

2) Recognizing humanitarian intervention as an 'emergency exit' from international law when the UN Security Council does not react due to a blockade of its decision-making process (the ad hoc strategy);

3) Introduction of subsidiary law to humanitarian intervention in the treaty or customary course outside the system of the Security Council (the exception strategy);

4) Introduction of a general law of humanitarian intervention in the treaty or customary course (the general right strategy).

It is seen prima facie that some of the above-mentioned strategies may in practice be faced with implementation difficulties. Firstly, the status quo strategy seems to be too conservative from the point of view of creating a new paradigm of sovereignty in international relations, not to mention duties erga omnes resulting from international human

110 Danish Institute of International Affairs, op. cit., at p. 27 and 112.

111 J.E. Rytter, Humanitarian Intervention without Security Council: From San Francisco to Kosovo - and Beyond, Nordic Journal of International Law 2001, Vol. 70, No. 1-2, at pp. 144-151 points to three solutions: maintaining of the existing status quo and exact interpretation of the UN Charter; development of the new doctrine of humanitarian intervention without UN Security Council either of subsidiary or competitive character in relation to the present competence of this organ; adoption of ad hoc strategy recognizing humanitarian intervention as an emergency exit justified either by necessity or by moral norms. 
rights protection. The last, in turn, would introduce a general right of humanitarian intervention which would be, on the one hand, a retreat from progress already made in international law and revert to the ius ad bellum concept whilst, on the other hand, it would pose a threat to the international order and collective security. The future seems to be located somewhere in between the strategies of "illegal extreme exception" and "subsidiary norm of international law".

This position is also acknowledged in the recent works of various specialists in international law. It must be stressed that proponents of humanitarian intervention are faced with a much more difficult task than their opponents who criticize this institution, particularly as relates to its functioning outside the UN system. For the latter, it suffices to adduce UN Charter regulations, whereas the former have to refer to rather sublime, and at times even breakneck theoretic-legal constructions. A. Buchanan has recently compiled a very interesting compilation of various commentators' views on humanitarian intervention ${ }^{112}$. According to the author, theoretical justification of legality (illegality) and legitimation of humanitarian intervention may be considered from three basic angles. The first justification is based on reference to extralegal norms - even if humanitarian intervention is illegal because it is undertaken without UN Security Council authorization, it is justified by moral necessity (Simple Moral Necessity Justification). Such approach is difficult for lawyers to accept, still it is consistent with the above described strategy of defining humanitarian intervention as an, albeit illegal, necessary "emergency exit". Hence, certain international lawyers, such as F.R. Tesón ${ }^{113}$, seek not only legitimation but also legalization of humanitarian intervention using moral principles and arguments. This position is defined by A. Buchanan with a seemingly shocking term "lawfulness illegality justification". It is an attempt to find a solution according to the rule of law in general. Even if intervention undertaken without UN Security Council authorization violates norms (e.g. Article 2(4) of the UN Charter), it is justified by

112 A. Buchanan, Reforming the International Law of Humanitarian Intervention, [in:] J.L. Holzgrefe, R.O. Keohane (eds), op. cit., at pp. 130-173.

113 F.R. Tesón, The Liberal Case for Humanitarian Intervention, [in:] Ibidem, at pp. 93-129; compare also of this author Humanitarian Intervention. An Inquiry into Law and Morality, $2^{\text {nd }}$ edition, Transnational Publishers, Irvington-Hudson 1997. 
certain core values of international law and the UN Charter in particular. From the standpoint of the theory of legal interpretation this, to some extent, gives less importance to the textual interpretation and advancing to the level of systematic interpretation. It would mean that to the abovementioned strategies de lege lata and de lege ferenda should be added one more - the strategy of systematic reinterpretation of the UN Charter. The third possible approach presented by A. Buchanan is equally shocking for lawyers. The author defines it as illegal legal reform. According to A. Buchanan, the existing system does not comply with the requirements and challenges facing the present age. It particularly concerns subjecting the permissibility of humanitarian intervention to a specific procedure of authorization by the UN Security Council. What does A. Buchanan suggest? In his opinion it is sometimes necessary to infringe existing law in order to reform the legal system. To support his view he points to two historic examples: illegal actions of British ships aiming to destroy the slave trade in the nineteenth century and the birth of the Nuremberg legal norms after $1945^{114}$.

It is clear that humanitarian intervention is fraught with complex ethical, political and legal problems both at practical and theoretical levels. The complexity of the matter has been long recognized in international law science. In 1895 T.J. Lawrence wrote: "in international law there are only a few issues as complicated as those concerning the legality of interventions"115. In this connection, we believe that the debate as to legality and legitimation will continue in the future. This assumption is confirmed by events which have taken place in recent years - in Sierra Leone, Liberia or East Timor directly, and in Afghanistan, Iraq and the international war on terrorism indirectly. To a certain extent the fact that a very clear-sighted and reasonable ICISS Report was recognized as the official UN document represents some consolation ${ }^{116}$. It facilitates further efforts to resolve problems concerning the legality and legitimation of

114 A. Buchanan, op. cit., at p. 136.

115 T.J. Lawrence, The Principles of International Law, London 1895, at p. 116 - quoted after S. Chesterman, op. cit., at p. 1.

116 There have already been first commentaries on the ICISS Report - see for example Forum: The International Commission on Intervention and State Sovereignty, The International Journal of Human Rights 2003, Vol. 7, No. 3, (including papers of A. Roberts, Intervention: One Step Forward in the Search for the Impossible; D. Warner, 
humanitarian intervention by compromise. The first real proposals for a multilateral convention on this matter have already been made ${ }^{117}$.

However, following the war in Iraq, the following question arose: "Is anyone interested in humanitarian intervention"? ${ }^{118}$ We wish to suggest a positive answer to this question and hope that this position is shared in contemporary literature on international relations, international law and legal philosophy ${ }^{119}$. T. Dunne, writing about new ways of conceptualizing international society, reminisced about the following story from Albert Einstein's life: "Professor Einstein, do you realize that this is the same exam paper that you set last year', said the examination officer. 'Ah', began the reply, 'the questions are the same, it's the answers that have changed" "120. This is equally apt to describe the moral, legal and political problems faced by humanitarian intervention.

Responsibility to Protect and the Limits of Imagination; R. Thakur, Reply in Defence of the Responsibility to Protect).

117 N.C. Crawford, Argument and Change in World Politics, Ethics, Decolonization and Humanitarian Intervention, Cambridge University Press 2002, at pp. 431-434.

118 S.N. MacFarlane, C.J. Thieking, T.G. Weiss, The responsibility to protect: is anyone interested in humanitarian intervention? Third World Quarterly 2004, Vol. 25, No. 5, at pp. 977-992.

119 See for example Roundtable: Humanitarian Intervention After 9/11, International Relations 2005, Vol. 19, No. 2, at p. 211-250 (with voices of T.J. Farer, D. Archibugi, C. Brown, N.C. Crawford, T.G. Weiss and N.J. Wheeler).

120 T. Dunne, New thinking on international society, British Journal of Politics and International Relations 2001, Vol. 3, No. 2, at p. 223. 